\title{
Luminescent and Proton Conducting Lanthanide Coordination Networks Based On a Zwitterionic Tripodal Triphosphonate
}

\author{
Montse Bazaga-García, ${ }^{\ddagger}$ Giasemi K. Angeli, ${ }^{\dagger}$ Konstantinos E. Papathanasiou, ${ }^{\dagger}$ Inés R. Salcedo, \\ Pascual Olivera-Pastor, ${ }^{\ddagger}$ Enrique R. Losilla, ${ }^{\ddagger}$ Duane Choquesillo-Lazarte, ${ }^{\S}$ Gary B. Hix, \\ Aurelio Cabeza, ${ }^{*}+\underset{*}{*}$ and Konstantinos D. Demadis ${ }^{* \dagger}$ \\ ${ }^{\dagger}$ Crystal Engineering, Growth and Design Laboratory, Department of Chemistry, University of Crete, Voutes Campus, Crete \\ GR-71003, Greece \\ ‡Departamento de Química Inorgánica, Universidad de Málaga, Campus Teatinos s/n, 29071 Málaga, Spain \\ ${ }^{\S}$ Laboratorio de Estudios Crystalográficos, IACT-CSIC, Granada, Spain \\ "School of Science and Technology, Nottingham Trent University, Clifton Lane, Nottingham NG118NS, United Kingdom
}

\author{
Supporting Information
}

\begin{abstract}
The synthesis, structural characterization, luminescence properties, and proton conduction performance of a new family of isostructural cationic $2 \mathrm{D}$ layered compounds are reported. These have the general formula $\left[\mathrm{Ln}\left(\mathrm{H}_{4} \mathrm{NMP}\right)\right.$ $\left.\left(\mathrm{H}_{2} \mathrm{O}\right)_{2}\right] \mathrm{Cl} \cdot 2 \mathrm{H}_{2} \mathrm{O}\left[\mathrm{Ln}=\mathrm{La}^{3+}, \mathrm{Pr}^{3+}, \mathrm{Sm}^{3+}, \mathrm{Eu}^{3+}, \mathrm{Gd}^{3+}, \mathrm{Tb}^{3+}\right.$, $\mathrm{Dy}^{3+}, \mathrm{Ho}^{3+}, \mathrm{H}_{6} \mathrm{NMP}=$ nitrilotris(methylphosphonic acid)], and contain $\mathrm{Cl}^{-}$as the counterion. In the case of $\mathrm{Ce}^{3+}$, a $1 \mathrm{D}$ derivative, $\left[\mathrm{Ce}_{2}\left(\mathrm{H}_{3} \mathrm{NMP}\right)_{2}\left(\mathrm{H}_{2} \mathrm{O}\right)_{4}\right] \cdot 4.5 \mathrm{H}_{2} \mathrm{O}$, isostructural with the known lanthanum compound has been isolated by simply crystallization at room temperature. The octa-coordinated environment of $\mathrm{Ln}^{3+}$ in $2 \mathrm{D}$ compounds is composed by six oxygen atoms from three different ligands and two oxygens from each bound water. Two of the three phosphonate groups

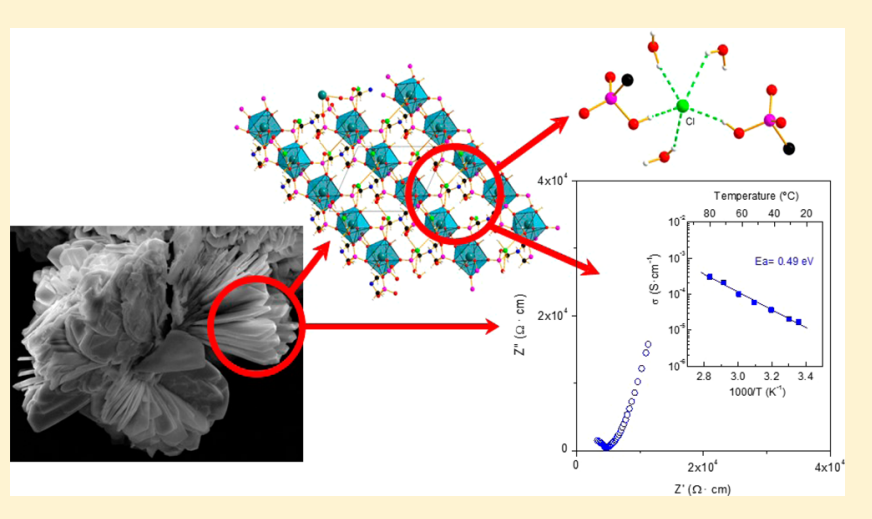
act as both chelating and bridging linkers, while the third phosphonate group acts solely as a bridging moiety. The materials are stable at low relative humidity at less at $170{ }^{\circ} \mathrm{C}$. However, at high relative humidity transform to other chloride-free phases, including the $1 \mathrm{D}$ structure. The proton conductivity of the $1 \mathrm{D}$ materials varies in a wide range, the highest values corresponding to the La derivative $\left(\sigma \approx 2 \times 10^{-3} \mathrm{~S} \cdot \mathrm{cm}^{-1}\right.$ at $\mathrm{RH} 95 \%$ and $\left.80^{\circ} \mathrm{C}\right)$. A lower proton conductivity, $3 \times 10^{-4} \mathrm{~S} \cdot \mathrm{cm}^{-1}$, was measured for $\left[\mathrm{Gd}\left(\mathrm{H}_{4} \mathrm{NMP}\right)\left(\mathrm{H}_{2} \mathrm{O}\right)_{2}\right] \mathrm{Cl} \cdot 2 \mathrm{H}_{2} \mathrm{O}$ at $80{ }^{\circ} \mathrm{C}$, which remains stable under the work conditions used. Absorption and luminescence spectra were recorded for selected $\left[\mathrm{Ln}\left(\mathrm{H}_{4} \mathrm{NMP}\right)\left(\mathrm{H}_{2} \mathrm{O}\right)_{2}\right] \mathrm{Cl} \cdot 2 \mathrm{H}_{2} \mathrm{O}$ compounds. In all of them, the observed transitions are attributed solely to $\mathrm{f}-\mathrm{f}$ transitions of the lanthanide ions present, as the $\mathrm{H}_{4} \mathrm{NMP}^{2-}$ organic group has no measurable absorption or luminescence properties.
\end{abstract}

\section{INTRODUCTION}

Metal organic frameworks (MOFs) and coordination polymers are at the epicenter of interest of modern chemical and materials research and technology. ${ }^{1}$ A significant area in this field concerns metal-phosphonate frameworks. ${ }^{2}$ These are topologically composed of an inorganic part (a metal ion or metal cluster) and the phosphonate linker. The latter is commonly a polyphosphonic acid in its deprotonated form. Phosphonic acids are generally strong acids possessing two acidic protons, having the $\mathrm{pKa} \mathrm{a}_{1}<1$ and the $\mathrm{pKa} \mathrm{a}_{2} \approx 7$. $^{3}$ Most reported metal phosphonates have been prepared in aqueous solutions at low $\mathrm{pH}$. The reason for limiting the synthetic efforts in the low $\mathrm{pH}$ regime is the propensity of metal phosphonates to rapidly precipitate at "higher" $\mathrm{pH}$ values, thus yielding amorphous or poorly crystalline materials.

In determining final properties of the solids, selection of the appropriate organic linker turns out a key factor not only because the metal-ligand connectivity determines the structural dimensionality but because it may contribute with specific functional groups. As a result, acidic groups usually remain in the structures upon crystallization, which are amenable to catalytic processes or promote hydrogen bond interactions with coordinated and/or lattice water molecules.

Nitrilotris(methylphosphonic acid), $\mathbf{H}_{6} \mathbf{N M P}$ (the subscript number indicates the number of acidic protons), is a prototype ligand largely used in the preparation of crystalline M(II)- and M(III)-phosphonate materials. ${ }^{4}$ The reaction with $\mathrm{M}(\mathrm{II})$ salts at a ligand-to-metal ratio 1:1 generated, in a quite predictable manner, isomorphic layered networks $\mathrm{M}^{\mathrm{II}}\left(\mathrm{H}_{2} \mathrm{O}\right)_{3}[\mathrm{HN}-$ $\left.\left(\mathrm{CH}_{2} \mathrm{PO}_{3} \mathrm{H}\right)_{3}\right]$, the resulting $2 \mathrm{D}$ corrugated sheets being formed from complementary hydrogen-bonding interaction

Received: March 11, 2016

Published: July 14, 2016 
between 1D helical polymers. ${ }^{5}$ Therefore, in these organoinorganic systems, hydrogen bonding, together with the presence of metal-coordinated water, most likely exerts the main control of the type of structure formed, irrespective of the metal ion employed.

On the other hand, combining rare-earth cations with polyphosphonate linkers represents a unique opportunity of engineering optical centers into photoluminescent materials, designing catalysts and developing other interesting functionalities into well-defined crystalline compounds, such as proton conduction, etc. ${ }^{2,6}$ Apart from the choice of phosphonic acid, dimensionality may also be mediated by the choice of experimental conditions. Thus, $1 \mathrm{D}$ and $2 \mathrm{D}$ lanthanidepolyphosphonate networks have been reported for the system Ln- ${ }_{6}$ NMP. ${ }^{7}$ Soft synthesis conditions (1 min microwave irradiation, $T=60{ }^{\circ} \mathrm{C}$ ), led to a $1 \mathrm{D}$ coordination polymer, composed of packed zigzag $\left[\mathrm{La}_{2}\left(\mathrm{H}_{3} \mathrm{NMP}\right)_{2}\left(\mathrm{H}_{2} \mathrm{O}\right)_{4}\right]$ chains embedded into a matrix of highly disordered water molecules. ${ }^{7 a}$ This compound is chemically and thermally (up to $100{ }^{\circ} \mathrm{C}$ ) stable, provided that coordinated water molecules remain attached to the metal centers. On the other hand, hydrothermal synthesis at $\mathrm{T}=165{ }^{\circ} \mathrm{C}$ yielded a series of $2 \mathrm{D}$ compounds $\left[\mathrm{Ln}\left(\mathrm{H}_{3} \mathrm{NMP}\right)\right] \cdot 1.5 \mathrm{H}_{2} \mathrm{O}\left[\mathrm{Ln}=\mathrm{La}^{3+}, \mathrm{Pr}^{3+}, \mathrm{Nd}^{3+}, \mathrm{Sm}^{3+}\right.$ and $\left.\mathrm{Eu}^{3+}\right]$ where the $\mathrm{Ln}^{3+}$ ions are exclusively coordinated to $\mathrm{H}_{3} \mathrm{NMP}^{3-}$ anions in neutral undulated layers. Interlayer spaces are filled up with lattice water molecules, which are engaged in hydrogenbonding interactions themselves and also with the $\mathrm{POH}$ groups. $^{\text {'b }}$ In addition, the material could be dehydrated at 200 ${ }^{\circ} \mathrm{C}$ without changing the structural features of the layers. Overall, the structural variations observed in lanthanide nitrilotris(methylphosphonate) compounds show that small changes in metal-ligand connectivity can promote important changes in properties, and hence, it could be possible to exploit them for specific purposes.

The strong H-bond networks exhibited by the $\mathrm{Ln}^{3+}$. nitrilotris(methylphosphonates), together with their considerable thermal stability make them potential candidates for evaluation of their proton conduction properties. Because these H-bonding networks confer potential proton conduction capabilities in a wide range of temperature and relative humidity, studies of proton conducting metal phosphonates have been overwhelming during the last five years. ${ }^{8}$

This paper is part of our continuing efforts to design, synthesize, structurally characterize, and, finally, study the proton conduction properties of several metal phosphonates with diverse structural topologies. ${ }^{6 g, 8,9}$ Herein, we describe the synthesis, structural characterization, luminescence properties, and proton conduction performance of a new family of cationic isostructural compounds, having the general formula [ $\mathrm{Ln}$ $\left.\left(\mathrm{H}_{4} \mathrm{NMP}\right)\left(\mathrm{H}_{2} \mathrm{O}\right)_{2}\right] \mathrm{Cl} \cdot 2 \mathrm{H}_{2} \mathrm{O}\left[\mathrm{Ln}=\mathrm{La}^{3+}, \mathrm{Pr}^{3+}, \mathrm{Sm}^{3+}, \mathrm{Eu}^{3+}, \mathrm{Gd}^{3+}\right.$, $\left.\mathrm{Tb}^{3+}, \mathrm{Dy}^{3+}, \mathrm{Ho}^{3+}\right]$ and containing $\mathrm{Cl}^{-}$as the counterion. By way of comparison, we also report the proton conductivity of the $1 \mathrm{D}$ compounds $\left[\mathrm{Ln}_{2}\left(\mathrm{H}_{3} \mathrm{NMP}\right)_{2}\left(\mathrm{H}_{2} \mathrm{O}\right)_{4}\right] \cdot 4.5 \mathrm{H}_{2} \mathrm{O}(\mathrm{Ln}=\mathrm{La}$, $\mathrm{Ce})$.

\section{EXPERIMENTAL SECTION}

Materials. Hydrated lanthanide nitrate or chloride reagents were purchased from Alfa-Aesar and used as received without further purification. Nitrilotris(methylphosphonic acid) $\left(\mathrm{H}_{6} \mathrm{NMP}, 50 \% \mathrm{w} / \mathrm{w}\right.$ solution in water as acid) was from ThermPhos, Switzerland. Stock solutions of $\mathrm{HCl}$ and $\mathrm{NaOH}$ were used for $\mathrm{pH}$ adjustments. In-house, deionized (DI) water was used for all syntheses.

Syntheses of $\left[\mathrm{Ln}\left(\mathrm{H}_{4} \mathrm{NMP}\right)\left(\mathrm{H}_{2} \mathrm{O}\right)_{2}\right] \mathrm{Cl} \cdot 2 \mathrm{H}_{2} \mathrm{O}\left[\mathrm{Ln}=\mathrm{La}^{3+}, \mathrm{Pr}^{3+}, \mathrm{Sm}^{3+}\right.$, $\left.\mathrm{Eu}^{3+}, \mathrm{Gd}^{3+}, \mathrm{Tb}^{3+}, \mathrm{Dy}^{3+}, \mathrm{Ho}^{3+}\right], \mathrm{Ln}-\mathrm{H}_{4} \mathrm{NMPCl}$. Typically a mixture of
$\mathrm{H}_{6} \mathrm{NMP}$ and the corresponding hydrated $\mathrm{Ln}^{3+}$ nitrate/chloride salt with a molar ratio 5:1 was prepared in water at room temperature as follows: $1.150 \mathrm{mmol}(750 \mu \mathrm{L})$ of the $50 \% \mathrm{w} / \mathrm{w} \mathrm{H}_{6} \mathrm{NMP}$, stock solution were added in DI water $(40 \mathrm{~mL})$. The $\mathrm{pH}$ of the ligand solution was then adjusted to $0.6-0.8$ by addition of $\mathrm{HCl}$. Then 0.230 mmol of $\mathrm{Ln}^{3+}$ salt were gradually added under constant stirring. Synthesis of the lighter $\mathrm{Ln}^{3+}$, i.e. $\mathrm{La}^{3+}$ through $\mathrm{Eu}^{3+}$, derivatives usually required additional $\mathrm{HCl}$ to reach the high $\mathrm{Cl}^{-} / \mathrm{Ln}^{3+}$ molar ratios, in some case $>9$, necessary to incorporate $\mathrm{Cl}^{-}$into the structures. In all cases, the final $\mathrm{pH}$ of the mixed solution was adjusted to $\sim 0.6$ with $\mathrm{HCl}$. After several days, crystals of the final products appeared. The crystals were collected by filtration and dried in air. Typical yields were $\sim 70 \%$. Further attempts to replace $\mathrm{Cl}^{-}$by other anions, such as $\mathrm{SO}_{4}{ }^{2-}$, $\mathrm{PO}_{4}{ }^{3-}$, and $\mathrm{Br}^{-}$in the same structure were unsuccessful.

Elemental CHN composition (\%) for $\mathrm{Ln}[\mathrm{HN}$ $\left.\left(\mathrm{CH}_{2} \mathrm{PO}_{3} \mathrm{H}\right)_{3}\left(\mathrm{H}_{2} \mathrm{O}\right)_{2}\right] \mathrm{Cl} \cdot 2 \mathrm{H}_{2} \mathrm{O}$ : Calcd for $\mathrm{La}-\mathrm{H}_{4} \mathrm{NMPCl}$ : $6.63 \% \mathrm{C}$, $3.34 \% \mathrm{H}, 2.58 \% \mathrm{~N}$. Found: $6.15 \% \mathrm{C}, 3.12 \% \mathrm{H}, 2.63 \% \mathrm{~N}$. Calcd for Pr $-\mathrm{H}_{4} \mathrm{NMPCl}: 6.60 \%$ C, 3.33\% H, 2.57\% N. Found: $6.15 \%$ C, 3.12\% H, $2.63 \%$ N. Calcd for $\mathrm{Sm}-\mathrm{H}_{4} \mathrm{NMPCl}$ : $6.48 \%$ C, $3.26 \% \mathrm{H}, 2.52 \% \mathrm{~N}$. Found: $6.12 \% \mathrm{C}, 3.18 \% \mathrm{H}, 2.56 \% \mathrm{~N}$. Calcd for $\mathrm{Eu}-\mathrm{H}_{4} \mathrm{NMPCl}: 6.48 \%$ C, $3.26 \%$ H, $2.52 \%$ N. Found: $6.12 \%$ C, $3.18 \%$ H, $2.56 \%$ N. Calcd for Gd- $\mathrm{H}_{4} \mathrm{NMPCl}: 6.40 \%$ C, 3.23\% H, 2.49\% N. Found: $6.21 \%$ C, $2.98 \%$ $\mathrm{H}, 2.49 \% \mathrm{~N}$. Calcd for $\mathrm{Tb}-\mathrm{H}_{4} \mathrm{NMPCl}$ : $6.40 \% \mathrm{C}, 3.23 \% \mathrm{H}, 2.49 \% \mathrm{~N}$. Found: $6.08 \% \mathrm{C}, 3.12 \% \mathrm{H}, 2.38 \% \mathrm{~N}$. Calcd for $\mathrm{Ho}-\mathrm{H}_{4} \mathrm{NMPCl}$ : $6.33 \%$ C, $3.19 \% \mathrm{H}, 2.46 \%$ N. Found: $6.11 \% \mathrm{C}, 3.08 \% \mathrm{H}, 2.41 \% \mathrm{~N}$. Calcd for Dy $-\mathrm{H}_{4} \mathrm{NMPCl}$ : $6.35 \%$ C, 3.63\% H, 2.47\% N. Found: $6.05 \%$ C, 3.99\% $\mathrm{H}, 2.50 \% \mathrm{~N}$.

Synthesis of $\left[\mathrm{Ce}_{2}\left(\mathrm{H}_{3} \mathrm{NMP}\right)_{2}\left(\mathrm{H}_{2} \mathrm{O}\right)_{4}\right] \cdot 4.5 \mathrm{H}_{2} \mathrm{O}, \mathrm{Ce}-\mathrm{H}_{3} \mathrm{NMP}$. The observation that $\mathrm{Cl}^{-} / \mathrm{Ce}^{3+}$ molar ratios lower than that required to synthesize $\left[\mathrm{Ln}\left(\mathrm{H}_{4} \mathrm{NMP}\right)\left(\mathrm{H}_{2} \mathrm{O}\right)_{2}\right] \mathbf{C l} \cdot 2 \mathbf{H}_{2} \mathrm{O}$ usually led to a different crystalline phase prompted us to further investigate this. The $\mathrm{Ce}^{3+}$ derivative was selected as a representative material. The title compound was isolated by using the $\mathrm{Ce}^{3+}$ nitrate salt and $\mathrm{H}_{2} \mathrm{SO}_{4}$ to adjust the $\mathrm{pH}$. Yield $\sim 70 \%$. Elemental $\mathrm{CHN}$ composition (\%) for $\mathrm{Ce}-$ $\mathrm{H}_{3}$ NMP. Calcd: $7.09 \%$ C, 3.63\% H, $2.76 \%$ N. Found: $6.76 \%$ C, $3.43 \%$ $\mathrm{H}, 2.38 \% \mathrm{~N}$.

Instrumentation. Elemental analyses $(\mathrm{C}, \mathrm{H}, \mathrm{N})$ were measured on a Perkin-Elmer 240 analyzer. Thermogravimetric analysis (TGA) data were recorded on an SDT-Q600 analyzer from TA Instruments. The temperature varied from RT to $900{ }^{\circ} \mathrm{C}$, at a heating rate of $10{ }^{\circ} \mathrm{C} / \mathrm{min}$. Measurements were carried out on samples in open platinum crucibles under a flow of air. Thermogravimetric analysis-mass spectrometry coupled was performed with a thermobalance Mettler Toledo (model TGA-DSC1), using the same heating rate and temperature range, but under a $\mathrm{N}_{2}$ flow of $50 \mathrm{~mL} / \mathrm{min}$. The analyzer was connected to a mass spectrometer (MS) of Pfeiffer Vacuum (model ThermoStar GSD 320). Gases compositions were evaluated by using MS, and gases evolution profiles were also obtained as a function of temperature.

Diffuse reflectance UV-vis spectra were recorded using a Jasco V670 spectrophotometer with a $60 \mathrm{~mm}$ integrating sphere. Photoluminescence spectra were recorded using the third harmonic of a $\mathrm{Nd}$ :Yag laser which excites the samples with radiation of $\lambda=355 \mathrm{~nm}$. For the standard PL spectra setup, an optical fiber is utilized to transmit the fluorescence signal to a UV-visible (300-1000 nm) spectrometer (S2000, Ocean Optics Inc. (OOI)), and the acquired spectrum can be interpreted via OOI software. A background spectrum of an empty sample holder was recorded prior to the sample spectra, which showed no response to the laser excitation. The materials were also investigated to see if there was any emission in the IR region (1000-2000 nm), but no responses were observed. For the $\mathrm{Eu}-\mathrm{H}_{4} \mathrm{NMPCl}$ derivative fluorescence emission measurements were carried out in an Edinburgh Instrument FLS920 fluorometer, using a $450 \mathrm{~W}$ Xe lamp as excitation source and a Starna 20-C support for solid samples. The excitation wavelength was $355 \mathrm{~nm}$, and the spectrum was registered using $2 \mathrm{~nm}$ excitation and emission slits opening and a dwell time of $0.2 \mathrm{~s}$.

Structural Determinations. Single crystal X-ray diffraction data for $\mathbf{L a}-\mathbf{H}_{4} \mathbf{N M P C l}$ was collected on a SMART $1 \mathrm{~K}$ CCD diffractometer at $150(2) \mathrm{K}$ with $\mathrm{Mo} \mathrm{K} \alpha(\lambda=0.71073 \AA)$. Single crystal X-ray diffraction data for $\mathbf{H o}-\mathbf{H}_{4} \mathbf{N M P C l}$ were collected on 
Table 1. Crystallographic Data for $\left.\mathrm{Ln}\left(\mathrm{H}_{4} \mathrm{NMP}\right)\left(\mathrm{H}_{2} \mathrm{O}\right)_{2}\right] \mathrm{Cl} \cdot 2 \mathrm{H}_{2} \mathrm{O}(\mathrm{Ln}=\mathrm{La}, \mathrm{Pr}, \mathrm{Sm}, \mathrm{Eu}, \mathrm{Gd}, \mathrm{Tb}, \mathrm{Dy}$ and $\mathrm{Ho})$ and $\left[\mathrm{Ce}_{2}\left(\mathrm{H}_{3} \mathrm{NMP}\right)_{2} \cdot\left(\mathrm{H}_{2} \mathrm{O}\right)_{4}\right] \cdot 4.5 \mathrm{H}_{2} \mathrm{O}$

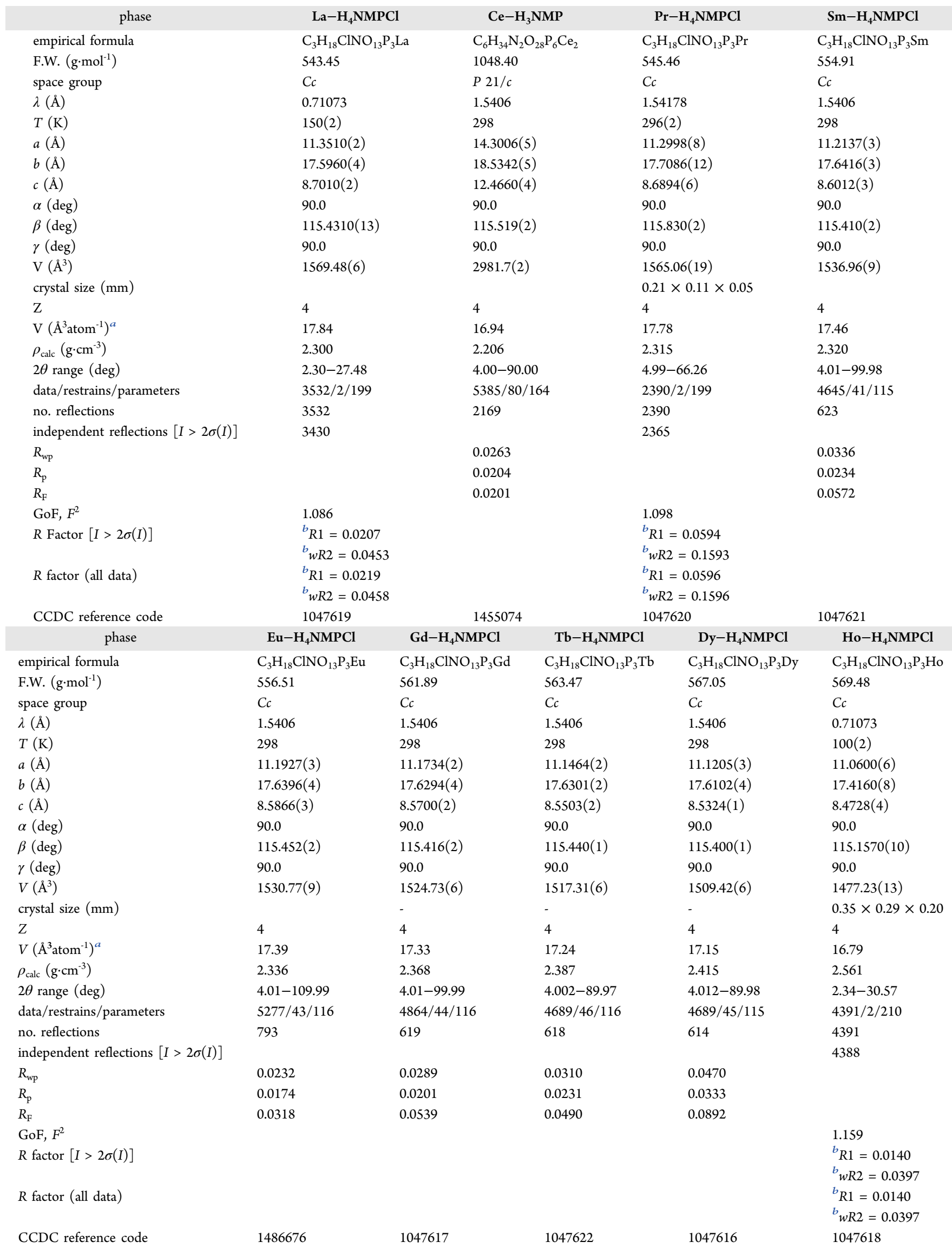


Table 1. continued

${ }^{a}$ Volume per non-hydrogen atom. ${ }^{b} \mathrm{R} 1(\mathrm{~F})=\Sigma|| \mathrm{Fo}|-| \mathrm{Fcl} / \Sigma|\mathrm{Fo}| ; \mathrm{wR} 2\left(\mathrm{~F}^{2}\right)=\left[\Sigma \mathrm{w}\left(\mathrm{Fo}^{2}-\mathrm{Fc}^{2}\right)^{2} / \Sigma \mathrm{F}^{4}\right]^{1 / 2}$.

Bruker D8 Venture and on a Bruker X8 Proteum for $\mathbf{P r}-\mathbf{H}_{4} \mathbf{N M P C l}$. The data were processed with APEX $2^{10}$ program and corrected for absorption using SADABS. ${ }^{11}$ The structures were solved by direct methods, which revealed the position of all non-hydrogen atoms. ${ }^{12}$ These atoms were refined on $\mathrm{F}^{2}$ by a full-matrix least-squares procedure using anisotropic displacement parameters. ${ }^{12}$ All hydrogen atoms were located in difference Fourier maps and included as fixed contributions riding on attached atoms with isotropic thermal displacement parameters $1.2(-\mathrm{C}-\mathrm{H})$ or $1.5(-\mathrm{O}-\mathrm{H})$ times those of the respective atom.

Laboratory X-ray powder diffraction (XRPD) patterns for Ln$\mathrm{H}_{4} \mathrm{NMPCl}(\mathrm{Ln}=\mathrm{Sm}, \mathrm{Eu}, \mathrm{Gd}, \mathrm{Tb}, \mathrm{Dy})$ were collected on a PANanalytical X'Pert Pro diffractometer using a Bragg-Brentano reflection configuration with $\mathrm{Ge}(111)$ primary monochromator $(\mathrm{Cu}$ $\left.\mathrm{K} \alpha_{1}\right)$ and X'Celerator detector. For $\mathbf{C e}-\mathbf{H}_{3} \mathbf{N M P}$ data were collected using a Empyrean PANalytical diffractometer $\left(\mathrm{Cu} \mathrm{K} \alpha_{1,2}\right)$ equipped with an PIXcel 1D detector in a Bragg-Brentano configuration. All scans were collected under sample spinning within the range of $4^{\circ}-$ $90^{\circ}(2 \theta)$ using a step size of 0.017 and a counting time between $300-$ $500 \mathrm{~s} /$ step. Crystal structures were refined by the Rietveld method, ${ }^{13}$ using the GSAS package, ${ }^{14}$ and the structures of $\left[\mathrm{La}_{2}\left(\mathrm{H}_{3} \mathrm{NMP}\right)_{2}\left(\mathrm{H}_{2} \mathrm{O}\right)_{4}\right] \cdot 4.5 \mathrm{H}_{2} \mathrm{O}^{7 a}$ (CCDC no. 1040381) and [La$\left.\left(\mathrm{H}_{4} \mathrm{NMP}\right)\left(\mathrm{H}_{2} \mathrm{O}\right)_{2}\right] \mathrm{Cl} \cdot 2 \mathrm{H}_{2} \mathrm{O}$ were used as structural models for the Rietveld refinements of $\mathbf{C e}-\mathbf{H}_{3} \mathrm{NMP}$ and $\mathrm{Ln}-\mathrm{H}_{4} \mathrm{NMPCl}(\mathrm{Ln}=\mathrm{Sm}$, $\mathrm{Eu}, \mathrm{Gd}, \mathrm{Tb}, \mathrm{Dy})$, respectively. Soft constraints were established to maintain chemically reasonable geometries for the phosphonate and $\mathrm{N}$ groups. The following soft constrains were used: $/ \mathrm{PO}_{3} \mathrm{C}$ tetrahedron/ $\mathrm{P}-\mathrm{O}[1.53(1) \AA], \mathrm{P}-\mathrm{C}[1.80(1) \AA], \mathrm{O} \cdots \mathrm{O}[2.55(1) \AA], \mathrm{O} \cdots \mathrm{C}$ [2.73(1) $\AA], \mathrm{C}-\mathrm{N}[1.50(1) \AA], \mathrm{C} \cdots \mathrm{C}[2.46(1) \AA]$, and $\mathrm{P} \cdots \mathrm{N}[2.77(1)$ $\AA]$. The final weight factors for the soft constrain histograms ranged between 10 and 20. Preferred orientation effects were minimized for polycrystalline samples $\mathrm{Ln}-\mathrm{H}_{4} \mathrm{NMPCl}(\mathrm{Ln}=\mathrm{Sm}, \mathrm{Eu}, \mathrm{Gd}, \mathrm{Tb}, \mathrm{Dy})$ by dilution and blended of the sample with spherical particles of Cab-OSil M-5 (Fluka) ${ }^{4 c}$ and it was refined along the [010] using the MarchDollase $^{15}$ correction. Crystallographic and structure refinement data are given in Table 1, and the final Rietveld plots for compounds $\mathbf{C e}-$ $\mathbf{H}_{3} \mathbf{N M P}$ and $\mathbf{L n}-\mathbf{H}_{4} \mathbf{N M P C l}(\mathrm{Ln}=\mathrm{Sm}, \mathrm{Eu}, \mathrm{Gd}, \mathrm{Tb}$, and $\mathrm{Dy})$ are given as Supporting Information (SI), Figures S1-S6. Crystal structures have been deposited at the CCDC, and the reference codes are also given in Table 1. Main bond distances are displayed in Table S1.

Thermodiffractometric studies at different relative humidity values were collected on a D8 ADVANCE (Bruker AXS) diffractometer equipped with a Johansson $\mathrm{Ge}(111)$ primary monochromator, which gives a strictly monochromatic Mo radiation $(\lambda=0.7093 \AA)$, and an Anton Paar MHC-trans chamber. The X-ray tube was operating at 50 $\mathrm{kV}$ and $50 \mathrm{~mA}$. The energy-dispersive linear detector LYNXEYE XE $500 \mu \mathrm{m}$, optimized for high energy radiation, was used with the maximum opening angle. Data were collected at the temperature range $25-120^{\circ} \mathrm{C}$, at low $(10 \%)$ relative humidity $(\mathrm{RH})$, and between 25 and $80{ }^{\circ} \mathrm{C}$, at $95 \% \mathrm{RH}$ using a heating rate of $1{ }^{\circ} \mathrm{C} / \mathrm{min}$. Samples, as thin pellets, were measured between 2 and $21^{\circ}(2 \theta)$ with a step size of $0.017^{\circ}$ and counting time of $192 \mathrm{~s} / \mathrm{step}$. Samples were hold at each temperature for $10 \mathrm{~min}$, before recording any pattern, giving sufficient time for any transformation to take place.

Proton Conductivity Studies. Impedance measurements were carried out on cylindrical pellets (diameter $\sim 5 \mathrm{~mm}$ and thickness $\sim 1$ $\mathrm{mm}$ ) obtained by pressing $40 \mathrm{mg}$ of sample at $250 \mathrm{MPa}$, for $1 \mathrm{~min}$. The pellets were pressed between porous $\mathrm{C}$ electrodes (Sigracet, GDL $10 \mathrm{BB}$, no Pt). The sample cells were placed inside a temperature- and humidity-controlled chamber (Espec SH-222) and connected to a HP4284A impedance analyzer. AC impedance data were collected over the frequency range from $20 \mathrm{~Hz}$ to $1 \mathrm{MHz}$ with an applied voltage of $1 \mathrm{~V}$. To equilibrate water content, pellets were first preheated $\left(0.2{ }^{\circ} \mathrm{C} / \mathrm{min}\right)$ from 25 to $80{ }^{\circ} \mathrm{C}$ at $10{ }^{\circ} \mathrm{C}$ intervals and $\mathrm{RH}$ $95 \%$. A stabilization time of $1 \mathrm{~h}$ was allowed at each temperature.
Impedance spectra were recorded on cooling using the same protocol and stabilization times of $1-2 \mathrm{~h}$. Water condensation on sample was avoided by reducing first the relative humidity before decreasing temperature. All measurements were electronically controlled by the winDETA package of programs. ${ }^{16}$

\section{RESULTS AND DISCUSSION}

All compounds with composition $\left[\mathrm{Ln}\left(\mathrm{H}_{4} \mathrm{NMP}\right)\left(\mathrm{H}_{2} \mathrm{O}\right)_{2}\right] \mathrm{Cl}$. $2 \mathrm{H}_{2} \mathrm{O}$ ( $\mathrm{Ln}=\mathrm{La}, \mathrm{Pr}, \mathrm{Sm}, \mathrm{Eu}, \mathrm{Gd}, \mathrm{Tb}, \mathrm{Dy}$ and $\mathrm{Ho}$ ) were obtained under soft conditions by crystallization at room temperature in contrast to other already reported layered and monodimensional lanthanide nitrilotris(methylphosphonates). Chloride ions are incorporated into the crystal structure by using $\mathrm{HCl}$ to adjust the reaction $\mathrm{pH}$. However, experiments conducted with $\mathrm{Ce}^{3+}$ ion using $\mathrm{Cl}^{-} / \mathrm{Ce}^{3+}$ molar ratios similar to those employed for other $\mathbf{L n}-\mathbf{H}_{4} \mathbf{N M P C l}$ systematically led to the $1 \mathrm{D}$ solid $\left[\mathrm{Ce}_{2}\left(\mathrm{H}_{3} \mathrm{NMP}\right)_{2}\left(\mathrm{H}_{2} \mathrm{O}\right)_{4}\right] \cdot 4.5 \mathrm{H}_{2} \mathrm{O}$, instead of the chlorinated compound. This compound is isostructural with the La derivative, previously obtained by hydrothermal and/or microwave-assisted procedures. ${ }^{7 \mathrm{a}}$

It is interesting to note that the very low $\mathrm{pH}(0.6)$ used for the synthesis is necessary for successful isolation of crystalline products. Lower $\mathrm{pH}$ values lead to no precipitation, and higher $\mathrm{pH}$ values result in rapid product precipitation and, consequently, low-crystallinity compounds. This is not unusual for lanthanide-containing phosphonate materials, and has been noted before by us for lanthanide-HPAA materials (HPAA = hydroxyphosphonoacetic acid). ${ }^{9 a}$ We attempted to further extend the series $\left.\left[\mathrm{LnH}_{4} \mathrm{NMP}\right)\left(\mathrm{H}_{2} \mathrm{O}\right)_{2}\right] \mathrm{Cl} \cdot 2 \mathrm{H}_{2} \mathrm{O}$ beyond the $\mathrm{Ho}^{3+}$ derivative but, at present, we have only isolated another, as of yet, unidentified phase corresponding to the $\mathrm{Er}^{3+}$ derivative.

We have also studied the morphological features of the crystalline products $\left[\mathrm{Ln}\left(\mathrm{H}_{4} \mathrm{NMP}\right)\left(\mathrm{H}_{2} \mathrm{O}\right)_{2}\right] \mathrm{Cl} \cdot 2 \mathrm{H}_{2} \mathrm{O}$ and $\left[\mathrm{Ce}_{2}\left(\mathrm{H}_{3} \mathrm{NMP}\right)_{2}\left(\mathrm{H}_{2} \mathrm{O}\right)_{4}\right] \cdot 4.5 \mathrm{H}_{2} \mathrm{O}$ by $\mathrm{SEM}$, see Figure 1. It appears that most of them are elongated rectangular plates, except the Ce compound, whose morphology resembles very thin needles. These rectangular plates show a tendency to aggregate, thus creating globular (see the La case) or flower-like (see the $\mathrm{Gd}$ or Sm cases) morphologies. The Ce compound seems to form very large, continuous aggregates $(>200 \mu \mathrm{m})$.

Crystal Structures. The synthesized [ $\mathrm{Ln}\left(\mathrm{H}_{4} \mathrm{NMP}\right)$ $\left.\left(\mathrm{H}_{2} \mathrm{O}\right)_{2}\right] \mathrm{Cl} \cdot 2 \mathrm{H}_{2} \mathrm{O}$ compounds ( $\mathrm{Ln}=\mathrm{La}, \mathrm{Pr}, \mathrm{Sm}, \mathrm{Eu}, \mathrm{Gd}, \mathrm{Tb}$, Dy and $\mathrm{Ho}$ ) are isostructural and crystallize in the space group Cc. Relevant structural details will be discussed for the $\mathrm{La}^{3+}$ derivative, as a representative compound of the series. The asymmetric part of the unit cell consist of one $\mathrm{La}^{3+}$ ion, two coordinated water molecules, one $\mathrm{H}_{4} \mathrm{NMP}^{2-}$ anionic ligand, two noncoordinated water molecules and one noncoordinated chloride ion (Figure 2a). The octa-coordinated environment of $\mathrm{La}^{3+}$ is composed by six oxygen atoms from three different ligands and two oxygens from each bound water. It must be noted that the three crystallographically independent phosphonate groups are monodeprotonated, and the nitrogen atom of the ligand is protonated, thus rendering $\mathrm{H}_{4} \mathrm{NMP}^{2-}$ a zwitterion. This is commonly encountered in other aminophosphonatetype compounds. ${ }^{17}$ Two of the three phosphonate groups act as both chelating and bridging linkers, while the third phosphonate group acts solely as a bridging moiety (Figure $2 b$ ). 

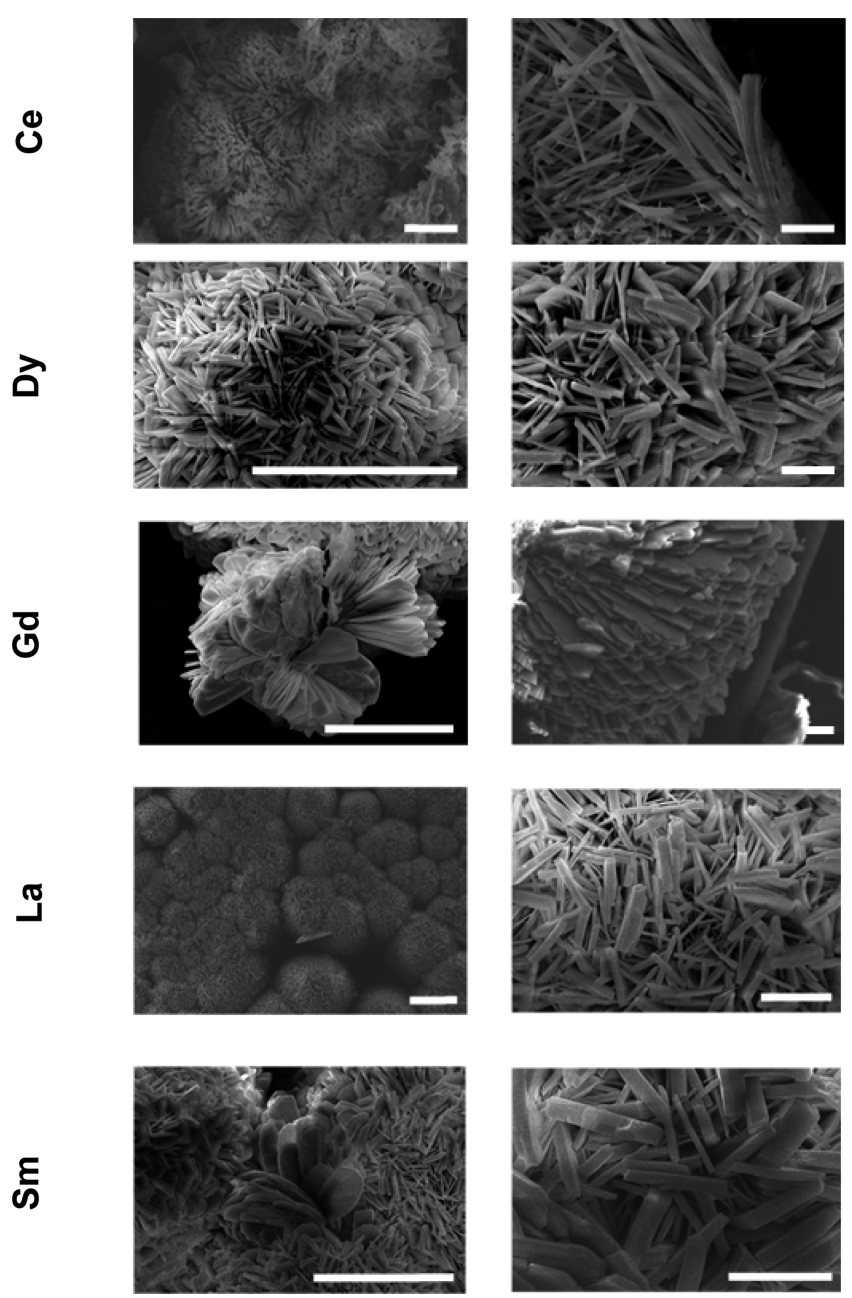

Figure 1. SEM images for $\left[\mathrm{Ce}_{2}\left(\mathrm{H}_{3} \mathrm{NMP}\right)_{2} \cdot\left(\mathrm{H}_{2} \mathrm{O}\right)_{4}\right] \cdot 4.5 \mathrm{H}_{2} \mathrm{O}$ and selected $\left[\mathrm{Ln}\left(\mathrm{H}_{4} \mathrm{NMP}\right)\left(\mathrm{H}_{2} \mathrm{O}\right)_{2}\right] \mathrm{Cl} \cdot 2 \mathrm{H}_{2} \mathrm{O}$ compounds. Scale bars for the left column images are $50 \mu \mathrm{m}$ and for the right column images are $10 \mu \mathrm{m}$.

The layers are built up from isolated $\mathrm{LnO}_{8}$ polyhedra and bridge chelating $\mathrm{NMP}^{2-}$ ligands. This connectivity creates infinite chains of interconnected $\mathrm{LnO}_{8}$ polyhedra (Figure 3a), instead of forming edge-sharing polyhedra chains typical of other 1D and 2D structures reported elsewhere. The positively charged layers are held together through charge-compensating chloride ions located in the interlayer region in addition to lattice water (Figure 3b).

Each chloride ion in the interlayer region is $\mathrm{H}$-bonded to two free $\mathrm{P}-\mathrm{OH}$ groups from adjacent layers $(\mathrm{O} 12$ and $\mathrm{O} 15)$ and three coordinated water molecules (Figure 4), two of them belonging to the same layer (O6, O14) and the third (O14) from an adjacent layer. Thus, this structure represents an unusual class of layered phosphonate with positively charged layers. Noncoordinated water molecules (O1 and O2) participate in linear $\mathrm{H}$-bond pathways by linking coordinated waters (O6 and $\mathrm{O} 14)$ and free $\mathrm{P}-\mathrm{OH}$ groups (O12, $\mathrm{O} 15$ and $\mathrm{O} 24)$ along the $a$-axis. Both coordinated water molecules of the same $\mathrm{LnO}_{8}$ polyhedron are linked by $\mathrm{H}$-bonds and contribute to the H-bond network.

The 1D coordination polymer, $\left[\mathrm{Ce}_{2}\left(\mathrm{H}_{3} \mathrm{NMP}\right)_{2}\left(\mathrm{H}_{2} \mathrm{O}\right)_{4}\right]$. $4.5 \mathrm{H}_{2} \mathrm{O}$, isostructural with the $\mathrm{La}^{3+}$ derivative reported elsewhere, ${ }^{7 a}$ was obtained by simple crystallization at room temperature without the necessity of using microwave irradiation or hydrothermal synthesis. In this solid, chains formed by edge sharing $\mathrm{LnO}_{9}$ polyhedra are connected through the $\mathrm{H}_{3} \mathrm{NMP}^{3-}$ ligands along the $a$ axis and interact with each other through noncoordinated water molecules by H-bonds. Both coordinated and noncoordinated waters also assist the creation of $\mathrm{H}$-bond pathways through interactions with the phosphonate groups (Figure S7, Table S2). The metal ion presents a distorted tricapped trigonal coordination environment formed by two water molecules and seven oxygen atoms originating from neighboring phosphonate groups.

On the other hand, the two-dimensional architecture reported for $\mathrm{Pr}-\mathrm{H}_{3} \mathrm{NMP} \cdot 1.5 \mathrm{H}_{2} \mathrm{O}^{7 \mathrm{~b}}$ is characterized by a $\mathrm{LnO}_{8}$ octa-coordination environment, with the ligand acting simultaneously as singly unidentate, chelating bidentate, and chelating tridentate. Such high connectivity prevents inclusion of water molecules in the first coordination sphere of the lanthanide ion, which, in this case, is exclusively coordinated by phosphonate oxygens. Hence the different modes of metalligand coordination are mostly responsible for the structural variability observed in the system $\mathrm{Ln}^{3+} / \mathrm{H}_{x} \mathrm{NMP}$.

Thermal Analyses. Thermogravimetric analyses for three representative $\left[\mathrm{Ln}\left(\mathrm{H}_{4} \mathrm{NMP}\right)\left(\mathrm{H}_{2} \mathrm{O}\right)_{2}\right] \mathrm{Cl} \cdot 2 \mathrm{H}_{2} \mathrm{O}$ samples $(\mathrm{Ln}=$ $\mathrm{Sm}, \mathrm{Gd}$, and Dy) are displayed in Figure 5. The TGA curves
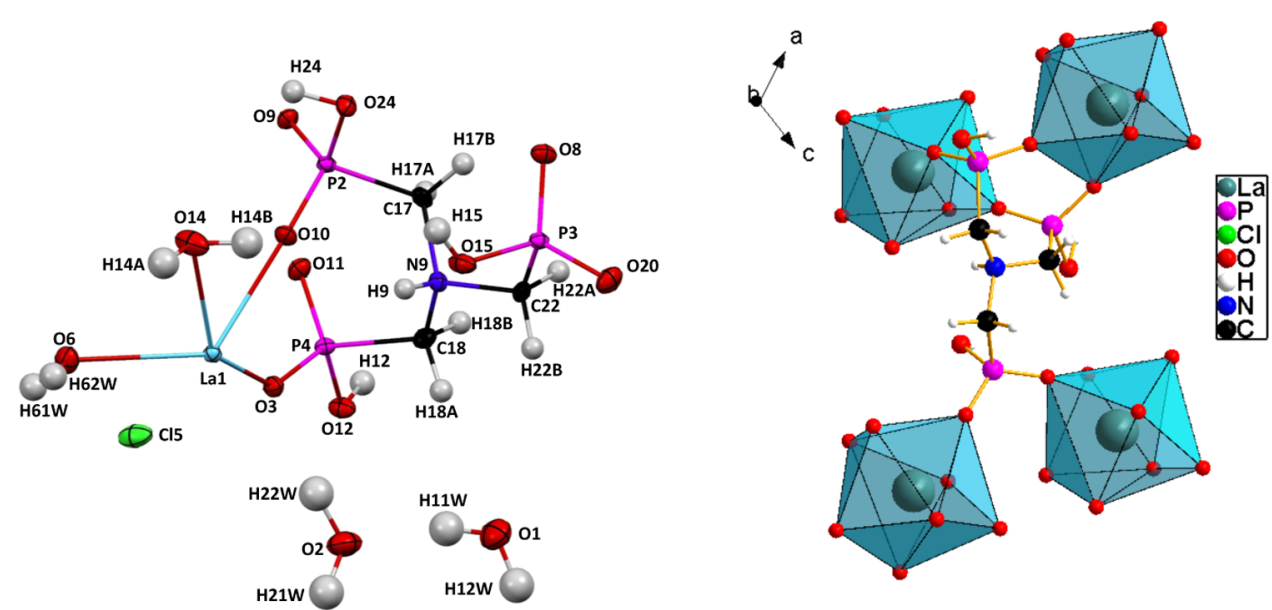

Figure 2. (a) Asymmetric unit cell with atoms labeled (non-hydrogen atoms drawn as thermal ellipsoids with $50 \%$ probability). (b) Coordination environment of 8-coordinated $\mathrm{La}^{3+}$ and $\mathrm{H}_{4} \mathrm{NMP}^{2-}$ ligand in the structure of $\left[\mathrm{La}\left(\mathrm{H}_{4} \mathrm{NMP}\right)\left(\mathrm{H}_{2} \mathrm{O}\right)_{2}\right] \mathrm{Cl}_{2} \cdot 2 \mathrm{H}_{2} \mathrm{O}$. 

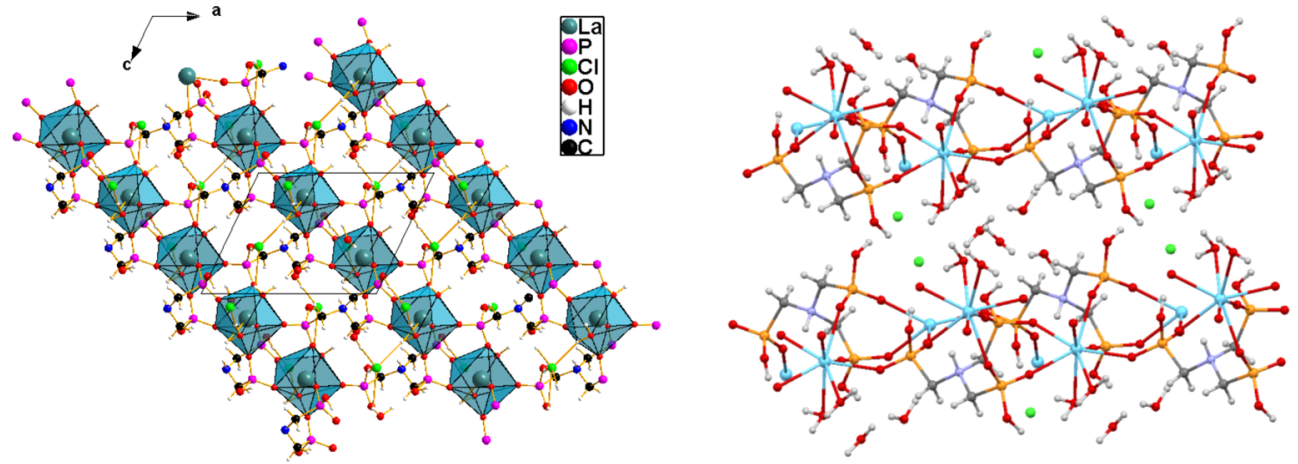

Figure 3. (a) View of a single layer in the structure of $\left[\mathrm{La}\left(\mathrm{H}_{4} \mathrm{NMP}\right)\left(\mathrm{H}_{2} \mathrm{O}\right)_{2}\right] \mathrm{Cl} \cdot 2 \mathrm{H}_{2} \mathrm{O}$ and (b) $2 \mathrm{D}$ adjacent layer showing chloride ions (green) and water molecules in the interlayer space.

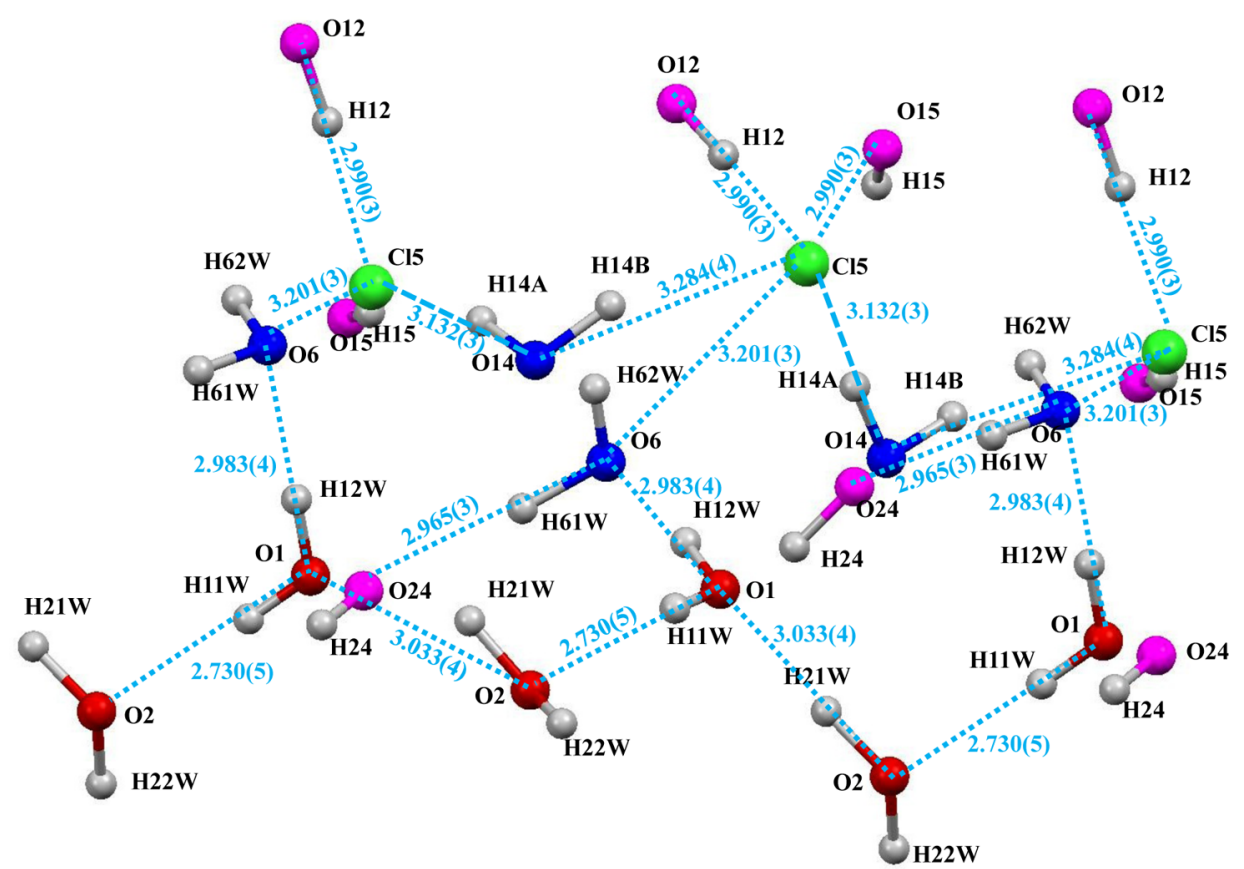

Figure 4. $\mathrm{H}$-bond network (donor-acceptor distances in $\AA$ ) in the interlayer region of $\left[\mathrm{La}\left(\mathrm{H}_{4} \mathrm{NMP}\right)\left(\mathrm{H}_{2} \mathrm{O}\right)_{2}\right] \mathrm{Cl}_{2} \cdot 2 \mathrm{H}_{2} \mathrm{O}$ between chloride anion (green), free $\mathrm{P}-\mathrm{OH}$ groups (magenta), coordinated water molecules (blue), and lattice water (red).

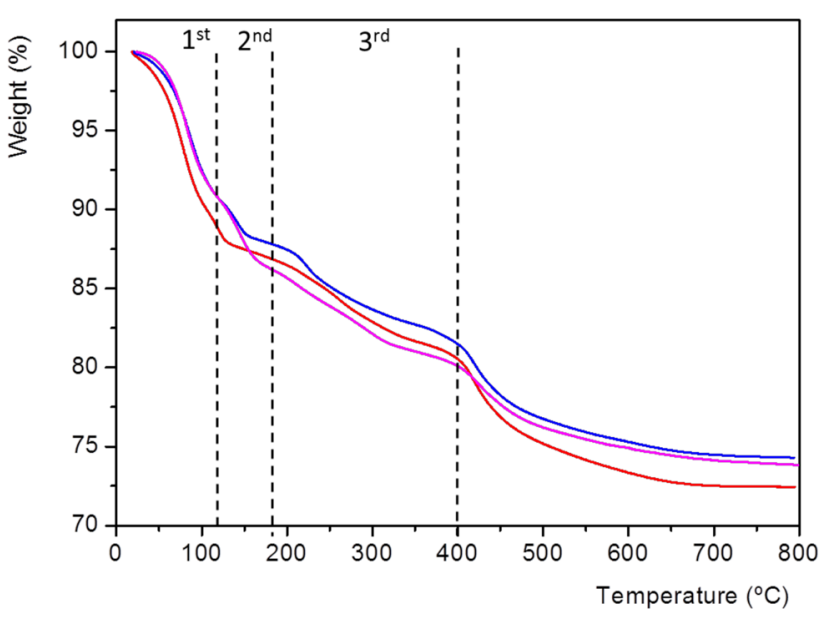

Figure 5. TGA curves for $\left[\mathrm{Ln}\left(\mathrm{H}_{4} \mathrm{NMP}\right)\left(\mathrm{H}_{2} \mathrm{O}\right)_{2}\right] \mathrm{Cl} \cdot 2 \mathrm{H}_{2} \mathrm{O}$ for $\mathrm{Sm}$ (red), Gd (blue), and Dy (magenta) derivatives.

show a weight loss in four steps. The first weight loss stage, up to $\sim 120{ }^{\circ} \mathrm{C}$, corresponds to the loss of two lattice plus one coordinated water molecules (observed $\sim 9.5 \%$, calculated $9.6 \%$ ). The second stage, up to $180{ }^{\circ} \mathrm{C}$, is characterized by a weight loss of $\sim 3.0 \%$ that corresponds to removal of the remaining bound water (calculated $3.2 \%$ ). The third weight loss stage $(\sim 6.0 \%)$, taking place in the range $180-400{ }^{\circ} \mathrm{C}$, may be attributed to removal of the majority of chloride ions as $\mathrm{HCl}$ (calculated 7.4\%) according to the TA-MS coupling results (Figures S8 and S9). Thermal decomposition of the ligand occurs between 400 and $650{ }^{\circ} \mathrm{C}(\sim 8.0 \%)$, slightly overlapping with the $\mathrm{HCl}$ removal. For all $\mathbf{L n}-\mathbf{H}_{4} \mathbf{N M P C l}$ samples, total weight losses were in the range 25.6-27.6\%. Thermal behavior of $\mathbf{C e}-\mathbf{H}_{3} \mathbf{N M P}$ agrees with that reported for lanthanum derivative, ${ }^{7 a}$ i.e., complete dehydration occurs around $150{ }^{\circ} \mathrm{C}$ (Figure S10).

Structural Stability of $\mathrm{Ln}-\mathrm{H}_{4} \mathrm{NMPCl}$. In order to evaluate possible structural changes upon heating, thermodiffraction studies (Figures 6) coupled with Rietveld refinements were carried out for sample $\mathbf{S m}-\mathbf{H}_{4} \mathbf{N M P C l}$, exposed to heating and cooling cycles in the range 25 to $120{ }^{\circ} \mathrm{C}$ at $\mathrm{RH} 10 \%$. At low relative humidity a slight increase of the cell volume is observed up to $80{ }^{\circ} \mathrm{C}$ after which the partial loss of water causes a 

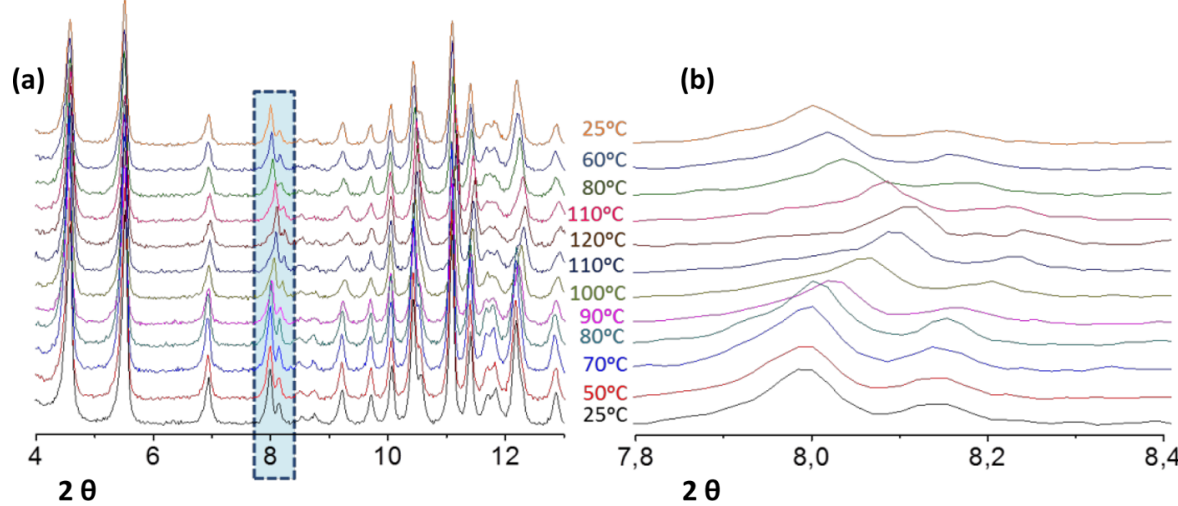

Figure 6. (a) Thermodiffraction patterns for $\mathrm{Sm}-\mathrm{H}_{4} \mathrm{NMPCl}$ at constant $\mathrm{RH}$ of $10 \%$ and (b) zoom corresponding to the shaded region.

progressive decrease of the $a$ and $b$ unit cell parameters (Figure S11), at least up to $120^{\circ} \mathrm{C}$. These structural changes, reversible on cooling, are attributed to a variation from 8 -fold to 7 -fold coordination environment of lanthanide centers as confirmed by Rietveld refinement for sample heated at $120{ }^{\circ} \mathrm{C}$ (Figure S12). Moreover, sample heating under air at $170{ }^{\circ} \mathrm{C}$ revealed that the structure rehydrated reversibly at room temperature (not shown).

The behavior of samples $\mathbf{L n}-\mathbf{H}_{\mathbf{4}} \mathbf{N M P C l}$ upon exposure at high $\mathrm{RH}(95 \%)$ and $80^{\circ} \mathrm{C}$ is not straightforward (Figure 7).

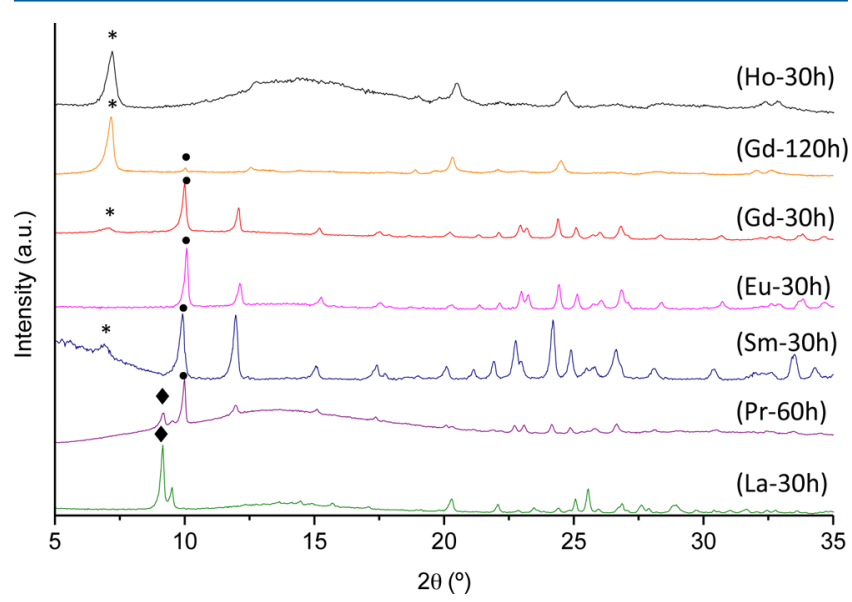

Figure 7. Powder XRD patterns for Ln-HNMPCl derivatives after treatment at $80{ }^{\circ} \mathrm{C}$ and $95 \% \mathrm{RH}$ and different times. The main diffraction peaks corresponding to the three detected phases are marked as ( ) $\left[\mathrm{Ln}_{2}\left(\mathrm{H}_{3} \mathrm{NMP}\right)_{2}\left(\mathrm{H}_{2} \mathrm{O}\right)_{4}\right] \cdot 4.5 \mathrm{H}_{2} \mathrm{O},(\mathrm{O})\left[\mathrm{Ln}\left(\mathrm{H}_{4} \mathrm{NMP}\right)\right.$ $\left.\left(\mathrm{H}_{2} \mathrm{O}\right)_{2}\right] \mathrm{Cl} \cdot 2 \mathrm{H}_{2} \mathrm{O}$, and $(*)$ unidentified.

La- and $\mathbf{P r}-\mathbf{H}_{4} \mathbf{N M P C l}$ compounds evolve to the $1 \mathrm{D}$ phase previously described, ${ }^{7}$ with lanthanum derivative being completely converted to this phase, as supported by Le Bail fit (Figure S13). In addition, the SEM/EDS analysis confirms removal of chloride ions from the structure. In such high humidity conditions, a structural rearrangement results by deprotonation of a phosphonate group and a concomitant change in the connectivity of the phosphonate groups, from a configuration of three equivalent bridging groups to another one in which bridge-chelating, bridge and singly unidentate coordination modes coexist. In absence of more precise structural data to elucidate the mechanism, it is thought that the chloride ions become increasingly mobile on changing metal/ligand connectivity and eventually are removed as $\mathrm{HCl}_{\mathrm{aq}}$ according to eq 1 . This arrangement causes breaking of the layer and a change in coordination from $\mathrm{LnO}_{8}$ to $\mathrm{LnO}_{9}$.

$$
\begin{aligned}
& 2\left[\mathrm{Ln}\left(\mathrm{H}_{4} \mathrm{NMP}\right)\left(\mathrm{H}_{2} \mathrm{O}\right)_{2}\right] \mathrm{Cl} \cdot 2 \mathrm{H}_{2} \mathrm{O}+x \mathrm{H}_{2} \mathrm{O} \\
& \quad \rightarrow\left[\mathrm{Ln}_{2}\left(\mathrm{H}_{3} \mathrm{NMP}\right)_{2}\left(\mathrm{H}_{2} \mathrm{O}\right)_{4}\right] \cdot 4.5 \mathrm{H}_{2} \mathrm{O}+2 \mathrm{HCl}_{\mathrm{aq}}
\end{aligned}
$$

Sm-, Eu- and $\mathbf{G d}-\mathbf{H}_{\mathbf{4}} \mathbf{N M P C l}$ derivatives practically maintained their structural integrity at $95 \% \mathrm{RH}$ and $80{ }^{\circ} \mathrm{C}$ provided that the treatment was $\leq 30 \mathrm{~h}$, although XRD patterns for Sm- and Gd- showed an additional small and broad peak at low angle corresponding to an unidentified phase (Figure 7). Moreover, at longer times $(120 \mathrm{~h})$, the Gd sample completely transformed to this unidentified phase, which was demonstrated by SEM/EDS analysis (not shown) to be a chloride-free compound. $\mathrm{Ho}-\mathrm{H}_{4} \mathrm{NMPCl}$ also evolved to the same chloridefree unidentified phase. Elemental and thermal analysis of this compound match well with the composition $\mathrm{Ho}[\mathrm{HN}$ $\left.\left(\mathrm{CH}_{2} \mathrm{PO}_{3}\right)\left(\mathrm{CH}_{2} \mathrm{PO}_{3} \mathrm{H}\right)_{2}\right] \cdot 1.5 \mathrm{H}_{2} \mathrm{O}$ (Calcd: $7.05 \% \mathrm{C}, 2.16 \%$ H, $2.72 \%$ N. Found: $7.09 \%$ C, 2.44\% H, 2.78\% N; TGA-weight loss at $200{ }^{\circ} \mathrm{C}$ : Calc: $5.30 \%$; Found: $5.86 \%$ ). This composition is identical to that corresponding to the $2 \mathrm{D}$ network described elsewhere ${ }^{7 \mathrm{~b}}$ for the series $\left[\mathrm{Ln}\left(\mathrm{H}_{3} \mathrm{NMP}\right)\right] \cdot 1.5 \mathrm{H}_{2} \mathrm{O}(\mathrm{Ln}=\mathrm{La}, \mathrm{Pr}$, $\mathrm{Nd}, \mathrm{Sm}$, and $\mathrm{Eu}$ ).

Regarding the structural stability of the monodimensional phases, the as-synthesized samples $\mathbf{C e}-\mathbf{H}_{3} \mathbf{N M P}$ (Figure S14) and $\mathbf{L a}-\mathbf{H}_{3} \mathbf{N M P}$, prepared as described elsewhere, ${ }^{7 \mathrm{a}}$ remained stable upon exposure at high $\mathrm{RH}$ at $80^{\circ} \mathrm{C}$, over a prolonged time period.

Proton Conductivity Studies. The variable H-bonding arrangement may be anticipated to confer distinct proton conductivities in solids as revealed for other metal phosphonates. ${ }^{2,8 \mathrm{~b}}$ Thus, a comparative impedance spectroscopic study was undertaken, aimed to establishing structure-proton conductivity correlations. Samples were equilibrated at each temperature to ensure stable conductivity values. For this study, two kinds of materials, $\mathbf{G d}-\mathbf{H}_{\mathbf{4}} \mathbf{N M P C l}$ and the chloride-free Ln derivatives ( $\mathrm{La}, \mathrm{Ce}, \mathrm{Gd}$, and $\mathrm{Ho}$ ), were selected. Postimpedance thermogravimetric analyses were conducted in order to check possible variations in the hydration state of samples during measurements. No changes were observed in all cases [see Figures S10 ( Ce- $\left.\mathbf{H}_{3} \mathbf{N M P}\right)$ and S15 (Gd$\mathbf{H}_{4} \mathbf{N M P C l}$ ) as examples].

Nyquist plots for samples equilibrated at 25 and $70{ }^{\circ} \mathrm{C}(95 \%$ $\mathrm{RH}$ ) are shown in Figure S16 for representative compounds. At high temperature, impedance plots show similar features with spikes inclined to the $\mathrm{Z}^{\prime}$ axis by $\sim 70^{\circ}$ with associated capacitances of $\sim 10 \mu \mathrm{F}$, indicating a partial blocking electrode 
response that allows limited diffusion and points to that the conducting species are $\mathrm{H}^{+}$ions. At lower temperatures, i.e., 25 ${ }^{\circ} \mathrm{C}$, broad arcs are observed at high frequencies with capacitances values of $\sim 10 \mathrm{pF}$ due to the bulk response. Total pellet resistances $\left(R_{\mathrm{T}}\right)$ values were obtained from the interception of the spike and/or the arc (low frequency end) on the $\mathrm{Z}^{\prime}$ axis.

The overall pellet conductivities, in a traditional Arrhenius plot, are given in Figure 8. $\mathbf{G d}-\mathbf{H}_{4} \mathbf{N M P C l}$ showed a proton

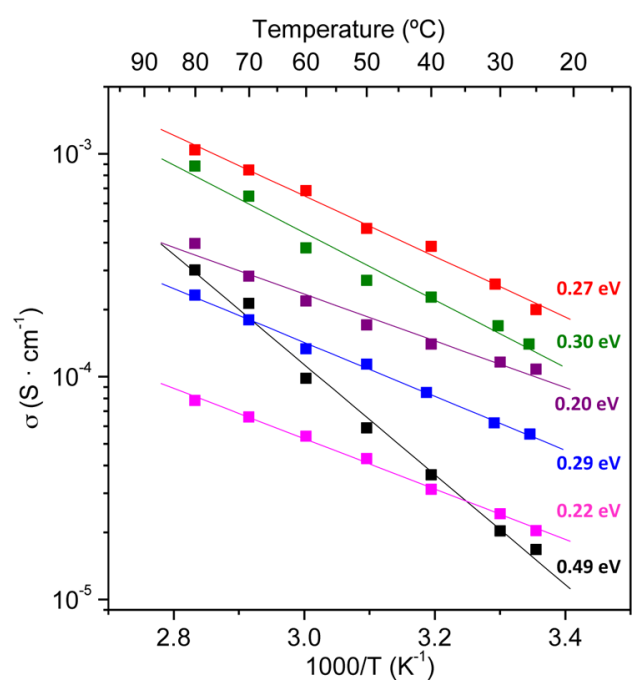

Figure 8. Arrhenius plot in the range $25-80{ }^{\circ} \mathrm{C}$ and $95 \% \mathrm{RH}$ for $\mathrm{La}-$ $\mathrm{H}_{3} \mathrm{NMP}$ (green), La- $\mathrm{H}_{3} \mathrm{NMP}$ as-synthesized (red), $\mathrm{Ce}-\mathrm{H}_{3} \mathrm{NMP}$ (pink), $\mathrm{Gd}-\mathrm{H}_{4} \mathrm{NMPCl}$ (black), and chloride-free Gd (purple) and Ho (blue) derivatives, respectively. Activation energy values are included for each compound.

conductivity of $3 \times 10^{-4} \mathrm{~S} \cdot \mathrm{cm}^{-1}\left(80^{\circ} \mathrm{C}\right)$ similar to those found for polycrystalline heterometallic $\mathrm{Co}-\mathrm{Ca}$ phosphonate $\left[\mathrm{Co}^{\mathrm{III}} \mathrm{Ca}^{\mathrm{II}}\left(\right.\right.$ notpH $\left.\left._{2}\right)\left(\mathrm{H}_{2} \mathrm{O}\right)_{2}\right] \mathrm{ClO}_{4} \cdot n \mathrm{H}_{2} \mathrm{O}\left[\right.$ notpH $_{6}=1,4,7$-triazacyclononane-1,4,7-triyl-tris(methylenephosphonic acid). ${ }^{18,19}$

The proton conductivity for the chloride-free compounds ranges between $2 \times 10^{-3}$ and $8 \times 10^{-5} \mathrm{~S} \cdot \mathrm{cm}^{-1}$, at $80{ }^{\circ} \mathrm{C}$ and $95 \% \mathrm{RH}$, for $\mathrm{La}$ and Ce derivatives. Both transformed and as synthesized $\mathrm{La}-\mathrm{H}_{3} \mathrm{NMP}$ compounds exhibited similar proton conductivities despite the fact that these samples were obtained by different methods, indicating that this property is characteristic of the coordination network rather than being an extrinsic feature. $^{20}$ It is also remarkable that the activation energies (0.2$0.3 \mathrm{eV}$ ) of these compounds were significantly lower than that exhibited by the chlorinated 2D material, $\mathbf{G d}-\mathbf{H}_{4} \mathbf{N M P C l}$, being typical of a Grotthuss proton transfer mechanism $(<0.5$ $\mathrm{eV})^{2}$

UV-vis and Photoluminescence (PL) Spectra of $\left[\mathrm{Ln}\left(\mathrm{H}_{4} \mathrm{NMP}\right)\left(\mathrm{H}_{2} \mathrm{O}\right)_{2}\right] \mathrm{Cl} \cdot 2 \mathrm{H}_{2} \mathrm{O}$ Compounds $\left[\mathrm{Ln}^{3+}=\mathrm{Pr}, \mathrm{Sm}\right.$, $\mathrm{Eu}, \mathrm{Gd}, \mathrm{Tb}, \mathrm{Dy}$, and Ho]. Absorption and luminescence spectra were recorded for selected $\mathrm{Ln}-\mathrm{H}_{4} \mathbf{N M P C l}$ compounds. In all of them, the observed transitions are attributed solely to $\mathrm{f}-\mathrm{f}$ transitions of the lanthanide ions present, as the $\mathrm{H}_{4} \mathrm{NMP}^{2-}$ organic group has no measurable absorption or luminescence properties. The electronic spectra for the studied samples show strong absorption bands below $\sim 250 \mathrm{~nm}$ assumed to arise from charge transfer transitions, i.e., $4 \mathrm{f}^{n} \rightarrow 4 \mathrm{f}^{n-1} 5 \mathrm{~d}^{1}$, which are "allowed" under all the selection rules, and therefore, they have been excluded from tables of band assignments. Figure 9 shows the UV-vis absorption and photoluminescence spectra, under excitation at $355 \mathrm{~nm}$, for $\mathbf{P r}-\mathbf{H}_{\mathbf{4}} \mathbf{N M P C l}$ with the corresponding band assignments (see also Table S3). Its absorption spectrum shows several intense peaks in the visible and NIR regions, with the spin-allowed $\Delta S=0$ transitions being much more intense than those which are spin-forbidden. Excitation of the sample with light of wavelength $355 \mathrm{~nm}$ gives rise to three peaks in the visible region corresponding to the ${ }^{3} \mathrm{P}_{0} \rightarrow{ }^{3} \mathrm{H}_{\mathrm{J}} \mathrm{U}=$ 4-6), the most intense of which is the middle one of the three, namely ${ }^{3} \mathrm{P}_{0} \rightarrow{ }^{3} \mathrm{H}_{5}$.

For $\mathbf{S m}-\mathbf{H}_{4} \mathbf{N M P C l}$ there are many states close to one another. In some cases, the width of the spectral bands precludes assignment to a specific transition, and encompasses a number of possibilities (Table S4). The most intense absorption transitions occur in the NIR region. These are the spin-allowed $(\Delta S=0){ }^{6} \mathrm{H}_{5 / 2} \rightarrow{ }^{6} \mathrm{~F}_{\mathrm{J}}$ transitions, with the relative weakness of the other transitions arising from the fact that they are spin-forbidden. Irradiation of the sample with light of wavelength $355 \mathrm{~nm}$, Figure S17, leads to three observable lines corresponding to ${ }^{4} \mathrm{G}_{5 / 2} \rightarrow{ }^{6} \mathrm{H}_{\mathrm{J}}(\mathrm{J}=9 / 2,7 / 2$, and $5 / 2)$. The first two of these are electric dipole transitions, while the latter, where $\Delta J=0$, will have a significant magnetic dipole contribution.

The emission properties of $\mathrm{Eu}^{3+}$ are well-known and the photoluminescent emission data for the $\mathrm{Eu}^{3+}$ derivative are consistent with those reported for other Eu-containing materials (see Figure S18 and Table S5). ${ }^{22}$ Emission for the ${ }^{5} \mathrm{D}_{0} \rightarrow{ }^{7} \mathrm{~F}_{4}$ transition is not observed as it is obscured by the broad, intense harmonic associated with the excitation source. The quality of the data is limited and so should be treated with some caution. However, the data do not show crystal field
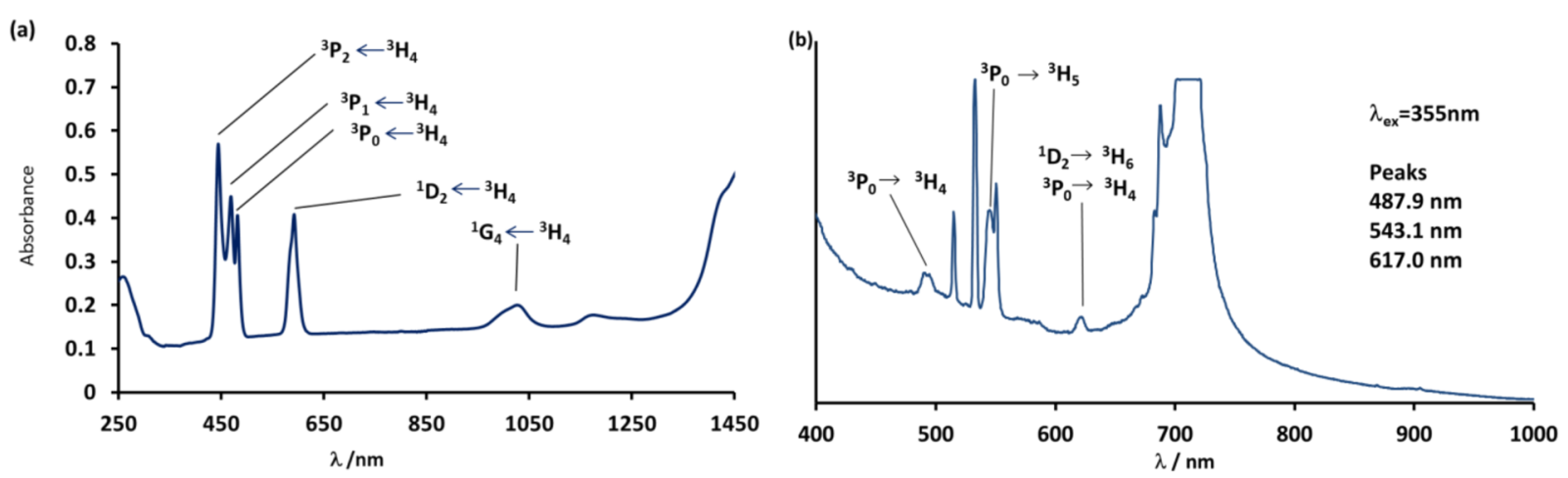

Figure 9. (a) UV-visible absorption and (b) photoluminescence spectra $\left(\lambda_{\mathrm{ex}}=355 \mathrm{~nm}\right)$ for $\mathbf{P r}-\mathbf{H}_{4} \mathbf{N M P C l}$. 

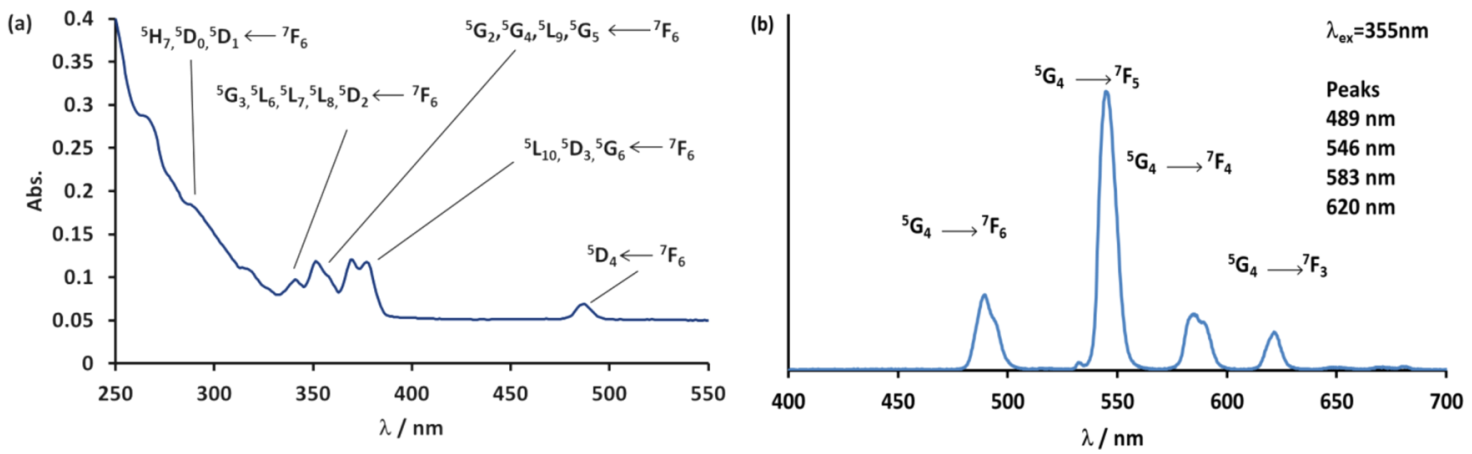

Figure 10. (a) UV-visible absorption and (b) photoluminescence spectra (under excitation al $355 \mathrm{~nm}$ ) of $\left[\mathbf{T b}\left(\mathrm{H}_{4} \mathbf{N M P}\right)\left(\mathrm{H}_{2} \mathbf{O}\right)_{2}\right] \mathbf{C l} \cdot 2 \mathrm{H}_{2} \mathbf{O}$.

splitting in this instance, which can indicate the low local symmetry around the $\mathrm{Eu}^{3+}$ ion.

What is interesting for this material is the number of peaks observed in the emission spectrum. At an excitation wavelength of $355 \mathrm{~nm}$, it feasible to populate the ${ }^{5} \mathrm{D}_{0},{ }^{5} \mathrm{D}_{1},{ }^{5} \mathrm{D}_{2}$, and the ${ }^{5} \mathrm{~L}_{6}$ excited states. Emissions arising from ${ }^{5} \mathrm{D}_{0} \rightarrow{ }^{7} \mathrm{~F}_{n}(n=0-4)$ are well-known and characterized and the ${ }^{5} \mathrm{D}_{0}$ excited state is usually populated directly or by radiationless relaxation from higher energy excited states, hence reported emission spectra for Eu-containing materials are usually restricted to the 550$710 \mathrm{~nm}$ range. In the data recorded for this sample, however, there are two strong peaks associated with transitions from excited states other than ${ }^{5} \mathrm{D}_{0}$; the ${ }^{5} \mathrm{~L}_{6} \rightarrow{ }^{7} \mathrm{~F}_{0}$ transition at 393 $\mathrm{nm}$, and the ${ }^{5} \mathrm{D}_{1} \rightarrow{ }^{7} \mathrm{~F}_{4}$ transition. Both are spin allowed $(\Delta S=$ 0 ) electric dipole transitions, and the former probably arises as a resonance from the excitation process.

The first excited state for $\mathrm{Gd}^{3+}$ lies in the UV region beyond $312 \mathrm{~nm}$ (Figure S19). In this instance the bands are not particularly strong and are hence assumed to arise from the spin forbidden $\mathrm{f}-\mathrm{f}$ transitions ${ }^{8} \mathrm{~S}_{7 / 2} \rightarrow{ }^{6} \mathrm{P}_{5 / 2}(296 \mathrm{~nm})$ and ${ }^{8} \mathrm{~S}_{7 / 2} \rightarrow$ ${ }^{6} \mathrm{I}_{7 / 2} \quad(274 \mathrm{~nm})$. No emission bands were observed upon excitation at any wavelength tried.

The $\mathrm{f}-\mathrm{f}$ transitions in the UV-visible part of the spectrum of $\mathbf{T b}-\mathbf{H}_{4} \mathbf{N M P C l}$ are fairly weak (Figure 10a). Interest lies in the breadth of the absorption envelope for this material, broadly covering all wavelengths measured below $400 \mathrm{~nm}$, which means that it can be readily excited by a wide range of energies. Its photoluminescence spectrum (Figure $10 \mathrm{~b}$ and Table S6) illuminated with light of wavelength $355 \mathrm{~nm}$, displays the strong ${ }^{5} \mathrm{G}_{4} \rightarrow{ }^{7} \mathrm{~F}_{J}(J=3-6)$ peaks commonly associated with the visible green response. The most intense peak is the ${ }^{5} \mathrm{G}_{4} \rightarrow$ ${ }^{7} \mathrm{~F}_{5}$ transition at $546 \mathrm{~nm}$. Interestingly, the only observable "resonance" wavelength (where absorption and emission have the same wavelength) is at $489 \mathrm{~nm}$. This implies that excitation to a higher energy excited state is followed by a nonradiative relaxation to the ${ }^{5} \mathrm{D}_{4}$ state prior to radiative relaxation to the ground states.

It is notable that a strong green emission is observed for material $\mathbf{T b}-\mathbf{H}_{4} \mathbf{N M P C l}$ despite the fact that $\mathrm{Tb}$ is the only lanthanide present. Excitation of an ion can migrate to a nearby neighbor if identical lanthanide ions are separated by only a few angstroms. The optical excitation is thus trapped at impurity or defect sites which ultimately gives rise to concentration quenching via the enhancement of nonradiative relaxation, or by ${ }^{5} \mathrm{D}_{3}+{ }^{7} \mathrm{~F}_{6} \rightarrow{ }^{5} \mathrm{D}_{4}+{ }^{7} \mathrm{~F}_{0}$ cross-relaxation and ultimately means that a visible luminescent response will have a much reduced intensity or may not be observed at all. ${ }^{23}$ As such it is usual to dope host materials with only $1-5 \mathrm{~mol} \%$ of the trivalent lanthanide ion. In $\mathbf{T b}-\mathbf{H}_{4} \mathbf{N M P C l}$, the $\mathrm{Tb}^{3+}$ ions are separated by distances of 5.588(2), 8.495(1), and 8.5503(2) $\AA$, which means that a high luminescent efficiency can be achieved even when all cationic sites are occupied by $\mathrm{Tb}$ ions.

The absorption spectrum of $\mathbf{D y}-\mathbf{H}_{\mathbf{4}} \mathbf{N M P C l}$, as shown in Figure S20a, shows the most intense peaks in the NIR region. The transitions observed in the UV-visible part of the spectrum are more resolved than in those reported in Dydoped phosphate glasses ${ }^{24}$ allowing for relatively straightforward assignment (Table S7). The luminescence spectrum $\left(\lambda_{\mathrm{ex}}\right.$ $=355 \mathrm{~nm}$ ), as shown in Figure S20b, is dominated by two strong peaks located at 483 and $573 \mathrm{~nm}$ corresponding to the ${ }^{4} \mathrm{~F}_{9 / 2} \rightarrow{ }^{6} \mathrm{H}_{15 / 2}$ and ${ }^{4} \mathrm{~F}_{9 / 2} \rightarrow{ }^{6} \mathrm{H}_{13 / 2}$ transitions. A weaker peak arising from the ${ }^{4} \mathrm{~F}_{9 / 2} \rightarrow{ }^{6} \mathrm{H}_{11 / 2}$ peak is observed at $651 \mathrm{~nm}$.

Finally, the UV-visible spectrum of $\mathbf{H o}-\mathbf{H}_{4} \mathbf{N M P C l}$ displays a large number of sharp absorption peaks (Figure S21), which lend themselves to straightforward assignment, as shown in Table S8. However, no luminescent response was detected for this sample under illumination at 355 or $266 \mathrm{~nm}$.

\section{CONCLUSIONS}

Herein, we reported a new family of isostructural cationic compounds having the general formula $\left[\mathrm{Ln}\left(\mathrm{H}_{4} \mathrm{NMP}\right)\left(\mathrm{H}_{2} \mathrm{O}\right)_{2}\right]$ $\mathrm{Cl} \cdot 2 \mathrm{H}_{2} \mathrm{O}$ ( $\mathrm{Ln}=\mathrm{La}, \mathrm{Pr}, \mathrm{Sm}, \mathrm{Eu}, \mathrm{Gd}, \mathrm{Tb}, \mathrm{Dy}$, and Ho). The positively charged $2 \mathrm{D}$ layers are held together by interlayer chloride ions, which form extended H-bond networks with uncoordinated $\mathrm{P}-\mathrm{OH}$ groups and with coordinated as well as lattice water molecules. In contrast to other $1 \mathrm{D}$ and $2 \mathrm{D}$ structures reported elsewhere, $\mathrm{LnO}_{8}$ polyhedra of the layer are isolated from each other, instead of forming edge-sharing polyhedra chains.

Reversible dehydration/hydration processes occur at low humidity (up to $170{ }^{\circ} \mathrm{C}$ ), while the $2 \mathrm{D}$ structure tends to become unstable upon heating at $80{ }^{\circ} \mathrm{C}$ and $95 \% \mathrm{RH}$, without following a straightforward behavior according to the $\mathrm{Ln}^{3+}$ ionic radius. A mechanism of phase transformation $2 \mathrm{D} \rightarrow 1 \mathrm{D}$, for $\mathrm{La}$ and $\operatorname{Pr}$ derivatives, in which metal/ligand reorganization is accompanied by removal of $\mathrm{HCl}$, is put forward. Conversely, $\mathrm{Sm}$ to Ho derivatives progressively transform into a distinct unidentified chloride-free semicrystalline phase.

Impedance measurements reveal that the chloride-free compounds, except $\left[\mathrm{Ce}_{2}\left(\mathrm{H}_{3} \mathrm{NMP}\right)_{2}\left(\mathrm{H}_{2} \mathrm{O}\right)_{4}\right] \cdot 4.5 \mathrm{H}_{2} \mathrm{O}$, are better proton conducting solids than the chlorinated $2 \mathrm{D} \mathrm{Gd}$ derivative. The latter exhibits a proton conductivity of $3 \times 10^{-4}$ $\mathrm{S} \cdot \mathrm{cm}^{-1}\left(80^{\circ} \mathrm{C}\right)$ at $95 \% \mathrm{RH}$, whereas those of $1 \mathrm{D}$ materials vary in the range $10^{-4}-10^{-3} \mathrm{~S} \cdot \mathrm{cm}^{-1}$, the highest values corresponding to the La derivative $\left(\sigma \approx 10^{-3} \mathrm{~S} \cdot \mathrm{cm}^{-1}\right.$ at $\mathrm{RH} 95 \%$ and 80 
$\left.{ }^{\circ} \mathrm{C}\right)$. The 1D solids show a typical Grotthuss proton transfer mechanism with low $E_{\mathrm{a}}$ values $(0.2-0.3 \mathrm{eV})$.

Absorbance and luminescence spectra were recorded for selected $\left[\mathrm{Ln}\left(\mathrm{H}_{4} \mathrm{NMP}\right)\left(\mathrm{H}_{2} \mathrm{O}\right)_{2}\right] \mathrm{Cl} \cdot 2 \mathrm{H}_{2} \mathrm{O}$ compounds. In all of them, the observed transitions are attributed solely to $\mathrm{f}-\mathrm{f}$ transitions of the lanthanide ions present, as the $\mathrm{H}_{4} \mathrm{NMP}^{2-}$ organic group has no measurable absorption or luminescence properties.

\section{ASSOCIATED CONTENT}

\section{S Supporting Information}

The Supporting Information is available free of charge on the ACS Publications website at DOI: 10.1021/acs.inorgchem.6b00570.

Rietveld plots for compounds $\left[\mathrm{Ce}_{2}\left(\mathrm{H}_{3} \mathrm{NMP}\right)_{2}\left(\mathrm{H}_{2} \mathrm{O}\right)_{4}\right]$. $4.5 \mathrm{H}_{2} \mathrm{O}$ and $\left[\mathrm{Ln}\left(\mathrm{H}_{4} \mathrm{NMP}\right)\left(\mathrm{H}_{2} \mathrm{O}\right)_{2}\right] \mathrm{Cl} \cdot 2 \mathrm{H}_{2} \mathrm{O}(\mathrm{Ln}=\mathrm{Sm}$, $\mathrm{Eu}, \mathrm{Gd}, \mathrm{Tb}, \mathrm{Dy})$. Extended hydrogen bonding interactions for $\left[\mathrm{Ce}_{2}\left(\mathrm{H}_{3} \mathrm{NMP}\right)_{2}\left(\mathrm{H}_{2} \mathrm{O}\right)_{4}\right] \cdot 4.5 \mathrm{H}_{2} \mathrm{O}$. TGMS curves for $\left[\mathrm{Gd}\left(\mathrm{H}_{4} \mathrm{NMP}\right)\left(\mathrm{H}_{2} \mathrm{O}\right)_{2}\right] \mathrm{Cl} \cdot 2 \mathrm{H}_{2} \mathrm{O}$. TGA curves for $\left[\mathrm{Ce}_{2}\left(\mathrm{H}_{3} \mathrm{NM}\right)_{2}\left(\mathrm{H}_{2} \mathrm{O}\right)_{4}\right] \cdot 4.5 \mathrm{H}_{2} \mathrm{O}$ as-synthesized and postimpedance analysis. Variation of unit cell parameters with the temperature for $\left[\mathrm{Sm}\left(\mathrm{H}_{4} \mathrm{NMP}\right)\right.$ $\left.\left(\mathrm{H}_{2} \mathrm{O}\right)_{2}\right] \mathrm{Cl} \cdot 2 \mathrm{H}_{2} \mathrm{O}$. Rietveld plot for $\left[\mathrm{Sm}\left(\mathrm{H}_{4} \mathrm{NMP}\right)\right.$ $\left.\left(\mathrm{H}_{2} \mathrm{O}\right)_{2}\right] \mathrm{Cl} \cdot 2 \mathrm{H}_{2} \mathrm{O}$ at $120{ }^{\circ} \mathrm{C}$ and $10 \% \mathrm{RH}$. Le Bail fit for $\left[\mathrm{La}_{2}\left(\mathrm{H}_{3} \mathrm{NMP}\right)_{2}\left(\mathrm{H}_{2} \mathrm{O}\right)_{4}\right] \cdot 4.5 \mathrm{H}_{2} \mathrm{O}$ obtained by exposing $\left[\mathrm{La}\left(\mathrm{H}_{4} \mathrm{NMP}\right)\left(\mathrm{H}_{2} \mathrm{O}\right)_{2}\right] \mathrm{Cl} \cdot 2 \mathrm{H}_{2} \mathrm{O}$ at $80{ }^{\circ} \mathrm{C}$ and $95 \%$ RH for 30 h. PXRD patterns for $\left[\mathrm{Ce}_{2}\left(\mathrm{H}_{3} \mathrm{NMP}\right)_{2}\left(\mathrm{H}_{2} \mathrm{O}\right)_{4}\right] \cdot 4.5 \mathrm{H}_{2} \mathrm{O}$ under nonambient conditions. TGA curves of $\left[\mathrm{Gd}\left(\mathrm{H}_{4} \mathrm{NMP}\right)\left(\mathrm{H}_{2} \mathrm{O}\right)_{2}\right] \mathrm{Cl}$. $2 \mathrm{H}_{2} \mathrm{O}$ as-synthesized and postimpedance. Complex impedance plane plots for $\left[\mathrm{Ce}_{2}\left(\mathrm{H}_{3} \mathrm{NMP}\right)_{2}\left(\mathrm{H}_{2} \mathrm{O}\right)_{4}\right]$. $4.5 \mathrm{H}_{2} \mathrm{O}$ and $\left[\mathrm{Gd}\left(\mathrm{H}_{4} \mathrm{NMP}\right)\left(\mathrm{H}_{2} \mathrm{O}\right)_{2}\right] \mathrm{Cl} \cdot 2 \mathrm{H}_{2} \mathrm{O}$ at 25 and $70{ }^{\circ} \mathrm{C}$ (95\% RH). UV-visible absorption and emission spectra for $\mathrm{Sm}-\mathrm{H}_{4} \mathrm{NMPCl}, \mathrm{Eu}-\mathrm{H}_{4} \mathrm{NMPCl}, \mathrm{Gd}-$ $\mathrm{H}_{4} \mathrm{NMPCl}, \mathrm{Dy}-\mathrm{H}_{4} \mathrm{NMPCl}$ and $\mathrm{Ho}-\mathrm{H}_{4} \mathrm{NMPCl}$. Selected bond distances for $\left[\mathrm{Ln}\left(\mathrm{H}_{4} \mathrm{NMP}\right)\left(\mathrm{H}_{2} \mathrm{O}\right)_{2}\right] \mathrm{Cl}$. $2 \mathrm{H}_{2} \mathrm{O}(\mathrm{Ln}=\mathrm{La}, \mathrm{Pr}, \mathrm{Sm}$. Eu, Gd, Tb, Dy Ho) and $\left[\mathrm{Ce}_{2}\left(\mathrm{H}_{3} \mathrm{NMP}\right)_{2}\left(\mathrm{H}_{2} \mathrm{O}\right)_{4}\right] \cdot 4.5 \mathrm{H}_{2} \mathrm{O}$. H-bond interactions

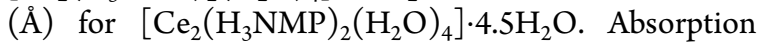
and emission bands for $\left[\mathrm{Ln}\left(\mathrm{H}_{4} \mathrm{NMP}\right)\left(\mathrm{H}_{2} \mathrm{O}\right)_{2}\right] \mathrm{Cl} \cdot 2 \mathrm{H}_{2} \mathrm{O}$ $(\mathrm{Ln}=\mathrm{Pr}, \mathrm{Sm}, \mathrm{Eu}, \mathrm{Gd}, \mathrm{Tb}, \mathrm{Dy}, \mathrm{Ho})$. (PDF)

CIF files for all structures. (CIF)

\section{AUTHOR INFORMATION}

\section{Corresponding Authors}

*E-mail: demadis@uoc.gr (K.D.D.).

*E-mail: aurelio@uma.es (A.C.).

\section{Notes}

The authors declare no competing financial interest.

\section{ACKNOWLEDGMENTS}

The work at UoC was funded by the Special Research Account (ELKE), project KA 2573. The work at UMA was funded by Spanish MINECO through MAT2013-41836-R which is cofunded by FEDER and by Junta de Andalucia through P12-FQM-1656 research projects. M.B.G. thanks UMA Research Plan for financial support. The work at NTU was funded by Nottingham Trent University. K.E. Papathanasiou thanks the Onassis Foundation for a doctoral scholarship.

\section{REFERENCES}

(1) (a) Special thematic issue on Metal Organic Frameworks. Chem. Rev. 2012, 112, 673-1268. (b) Special thematic issue on Hybrid Materials. Chem. Soc. Rev. 2011, 40, 453-1152.10.1039/c1cs90002a (c) Themed issue on Metal-Organic Frameworks. Chem. Soc. Rev. 2009, 38, 1201-1508.10.1039/b906666g (d) McDonald, T. M.; Lee, W. R.; Mason, J. A.; Wiers, B. M.; Hong, C. S.; Long, J. R. J. Am. Chem. Soc. 2012, 134, 7056-7065. (e) Cirujano, F. G.; Llabrés i Xamena, F. X.; Corma, A. Dalton Trans. 2012, 41, 4249-4254. (f) Nasalevich, M. A.; van der Veen, M.; Kapteijn, F.; Gascon, J. CrystEngComm 2014, 16, 4919-4926. (g) He, Y.; Zhou, W.; Yildirim, T.; Chen, B. Energy Environ. Sci. 2013, 6, 2735-2744.

(2) Metal Phosphonate Chemistry: From synthesis to applications; Clearfield, A., Demadis, K. D., Ed.; The Royal Society of Chemistry: London, 2012.

(3) (a) Ichikawa, T.; Sawada, K. Bull. Chem. Soc. Jpn. 1997, 70, 2111-2123. (b) Ruiz-Agudo, E.; Rodriguez-Navarro, C.; SebastianPardo, E. Cryst. Growth Des. 2006, 6, 1575-1583. (c) Popov, K.; Rönkkömäki, H.; Lajunen, L. H. J. Pure Appl. Chem. 2006, 78, 663675 .

(4) (a) Cabeza, A.; Ouyang, X.; Sharma, C. V. K.; Aranda, M. A. G.; Bruque, S.; Clearfield, A. Inorg. Chem. 2002, 41, 2325-2333. (b) Cabeza, A.; Bruque, S.; Guagliardi, A.; Aranda, M. A. G. J. Solid State Chem. 2001, 160, 278-286. (c) Cabeza, A.; Aranda, M. A. G.; Bruque, S. J. Mater. Chem. 1999, 9, 571-578. (d) Somov, N. V.; Chausov, F. F.; Zakirova, R. M.; Fedotova, I. V. Russ. J. Coord. Chem. 2015, 41, 798-804. (e) Demadis, K. D.; Katarachia, S. D.; Koutmos, M. Inorg. Chem. Commun. 2005, 8, 254-258.

(5) (a) Sharma, C. V. K.; Clearfield, A.; Cabeza, A.; Aranda, M. A. G.; Bruque, S. J. Am. Chem. Soc. 2001, 123, 2885-2886. (b) Demadis, K. D.; Katarachia, S. D. Phosphorus, Sulfur Silicon Relat. Elem. 2004, 179, 627-648. (c) Demadis, K. D.; Katarachia, S. D.; Zhao, H.; Raptis, R. G.; Baran, P. Cryst. Growth Des. 2006, 6, 836-838.

(6) (a) Vilela, S. M. F.; Ananias, D.; Gomes, A. C.; Valente, A. A.; Carlos, L. D.; Cavaleiro, J. A. S.; Rocha, J.; Tomé, J. P. C.; Paz, F. A. A. J. Mater. Chem. 2012, 22, 18354-18371. (b) Vilela, S. M. F.; Firmino, A. D. G.; Mendes, R. F.; Fernandes, J. A.; Ananias, D.; Valente, A. A.; Ott, H.; Carlos, L. D.; Rocha, J.; Tomé, J. P. C.; Paz, F. A. A. Chem. Commun. 2013, 49, 6400-6402. (c) Paz, F. A. A.; Vilela, S. M. F.; Tomé, J. P. C. Cryst. Growth Des. 2014, 14, 4873-4877. (d) Shi, F.-N.; Paz, F. A. A.; Ribeiro-Claro, P.; Rocha, J. Chem. Commun. 2013, 49, 11668-11670. (e) Paz, F. A. A.; Klinowski, J.; Vilela, S. M. F.; Tomé, J. P. C.; Cavaleiro, J. A. S.; Rocha, J. Chem. Soc. Rev. 2012, 41, 10881110. (f) Rocha, J.; Carlos, L. D.; Paz, F. A. A.; Ananias, D. Chem. Soc. Rev. 2011, 40, 926-940. (g) Colodrero, R. M. P.; Olivera-Pastor, P.; Losilla, E. R.; Aranda, M. A. G.; Leon-Reina, L.; Papadaki, M.; McKinlay, A. C.; Morris, R. E.; Demadis, K. D.; Cabeza, A. Dalton Trans. 2012, 41, 4045-4051.

(7) (a) Mendes, R. F.; Silva, P.; Antunes, M. M.; Valente, A. A.; Almeida Paz, F. A. Chem. Commun. 2015, 51, 10807-10810. (b) Cunha-Silva, L.; Mafra, L.; Ananias, D.; Carlos, L. D.; Rocha, J.; Almeida-Paz, F. A. Chem. Mater. 2007, 19, 3527-3538. (c) Silva, P.; Vieira, F.; Gomes, A. C.; Ananias, D.; Fernandes, J. A.; Bruno, S. M. J. Am. Chem. Soc. 2011, 133, 15120-15138. (d) Silva, P.; Fernandes, J. A.; Almeida Paz, F. A. Acta Crystallogr., Sect. E: Struct. Rep. Online 2012, 68, m294-m295.

(8) (a) Shimizu, G. K. H. In Metal Phosphonate Chemistry: From Synthesis to Applications; Clearfield, A., Demadis, K., Eds.; The Royal Society of Chemistry: London, 2012; pp 493-524. (b) Cabeza, A.; Olivera-Pastor, P.; Colodrero, R. M. P. Tailored Organic-Inorganic Materials; Brunet, E., Colón, J. L., Clearfield, A., Eds.; John Wiley \& Sons, Inc.: New York, 2015; Chapter 4, pp 137-191. (c) Kim, S.; Dawson, K. W.; Gelfand, B. S.; Taylor, J. M.; Shimizu, G. K. H. J. Am. Chem. Soc. 2013, 135, 963-966. (d) Shimizu, G. K. H.; Taylor, J. M.; Kim, S. Science 2013, 341, 354-355. (e) Donnadio, A.; Nocchetti, M.; Costantino, F.; Taddei, M.; Casciola, M.; Silva-Lisboa, F.; Vivani, R. Inorg. Chem. 2014, 53, 13220-13226. (f) Ramaswamy, P.; Wong, N. E.; Gelfand, B. S.; Shimizu, G. K. H. J. Am. Chem. Soc. 2015, 137, 7640-7643. (g) Furukawa, H.; Cordova, K. E.; O’Keeffe, M.; Yaghi, 
O. M. Science 2013, 341, 1230444. (h) Su, X.; Yao, Z.; Ye, Y.; Zeng, H.; Xu, G.; Wu, L.; Ma, X.; Chen, Q.-H.; Wang, L.; Zhang, Z.; Xiang, S. Inorg. Chem. 2016, 55, 983.

(9) (a) Colodrero, R. M. P.; Papathanasiou, K. E.; Stavgianoudaki, N.; Olivera-Pastor, P.; Losilla, E. R.; Aranda, M. A. G.; León-Reina, L.; Sanz, J.; Sobrados, I.; Choquesillo-Lazarte, D.; García-Ruiz, J. M.; Atienzar, P.; Rey, F.; Demadis, K. D.; Cabeza, A. Chem. Mater. 2012, 24, 3780-3792. (b) Bazaga-García, M.; Colodrero, R. M. P.; Papadaki, M.; Garczarek, P.; Zoń, J.; Olivera-Pastor, P.; Losilla, E. R.; LeónReina, L.; Aranda, M. A. G.; Choquesillo-Lazarte, D.; Demadis, K. D.; Cabeza, A. J. Am. Chem. Soc. 2014, 136, 5731-5739. (c) Colodrero, R. M. P.; Angeli, G. K.; Bazaga-García, M.; Olivera-Pastor, P.; Villemin, D.; Losilla, E. R.; Martos, E. Q.; Hix, G. B.; Aranda, M. A. G.; Demadis, K. D.; Cabeza, A. Inorg. Chem. 2013, 52, 8770-8783. (d) BazagaGarcía, M.; Papadaki, M.; Colodrero, R. M. P.; Olivera-Pastor, P.; Losilla, E. R.; Nieto-Ortega, B.; Aranda, M. A. G.; Choquesillo-Lazarte, D.; Cabeza, A.; Demadis, K. Chem. Mater. 2015, 27, 424-435.

(10) Bruker, APEX2 Software, V2012.2; Bruker AXS Inc.: Madison, WI, 2012.

(11) Sheldrick, G. M. SADABS, Program for Empirical Absorption Correction of Area Detector Data; University of Göttingen: Göttingen, Germany, 2012.

(12) Sheldrick, G. M. Acta Crystallogr., Sect. A: Found. Crystallogr. 2008, 64, 112-122.

(13) Rietveld, H. M. J. Appl. Crystallogr. 1969, 2, 65-71.

(14) Larson, A. C.; von Dreele, R. B. General Structure Analysis System (GSAS), Los Alamos National Laboratory Report LAUR 86-748; Los Alamos National Laboratory: Los Alamos, NM, 2004.

(15) Dollase, W. A. J. Appl. Crystallogr. 1986, 19, 267-272.

(16) winDETA; Novocontrol GmbH: Hundsangen, Germany, 1995.

(17) Papathanasiou, K. E.; Demadis, K. D. In Tailored OrganicInorganic Materials; Brunet, E., Colón, J. L., Clearfield, A., Eds.; John Wiley \& Sons, Inc.: New York, 2015; Chapter 3, pp 83-135.

(18) (a) Feyand, M.; Seidler, C. F.; Deiter, C.; Rothkirch, A.; Lieb, A.; Wark, M.; Stock, N. Dalton Trans. 2013, 42, 8761-8770.

(b) Taylor, J. M.; Mah, R. K.; Moudrakovski, I. L.; Ratcliffe, C. I.; Vaidhyanathan, R.; Shimizu, G. K. H. J. Am. Chem. Soc. 2010, 132, 14055-14057.

(19) Bao, S.-S.; Li, N.-Z.; Taylor, J. M.; Shen, Y.; Kitagawa, H.; Zheng, L.-M. Chem. Mater. 2015, 27, 8116-8125.

(20) Tominaka, S.; Cheetham, A. K. RSC Adv. 2014, 4, 5438254387.

(21) (a) van Grotthuss, C. J. D. Ann. Chim. 1806, 58, 54-73. (b) Colomban, P. Proton Conductors: Solids, Membranes and Gels Materials and Devices. Chemistry of Solid State Materials; Cambridge University Press: Cambridge, U.K., 1992; Vol. 2.

(22) Binnemans, K.; Deun, R. V.; Görller-Walrand, C.; Adam, J. L. J. Non-Cryst. Solids 1998, 238, 11-29.

(23) Shionoya, S.; Yen, W. M. Phosphor Handbook; Kano, T., Ed.,

CRC Press Inc.: Boca Raton, FL, 1999; pp 177-200.

(24) Yen, W. M.; Shionoya, S.; Yamamoto, H. Phosphor Handbook, 2nd ed.; Kano, T., Ed.; CRC Press Inc.: Boca Raton, FL, 2006. 